Article

\title{
Effects of Ambient Ozone on Soybean Biophysical Variables and Mineral Nutrient Accumulation
}

\author{
Vasit Sagan $1, *(\mathbb{D})$, Matthew Maimaitiyiming ${ }^{1}$ (D) and Jack Fishman ${ }^{1,2}$ \\ 1 Department of Earth and Atmospheric Sciences, Saint Louis University, St. Louis, MO 63108, USA; \\ matt.maimaitiyiming@slu.edu (M.M.); jack.fishman@slu.edu (J.F.) \\ 2 Center for Environmental Sciences, Saint Louis University, St. Louis, MO 63108, USA \\ * Correspondence: vasit.sagan@slu.edu; Tel.: +1-314-977-5156
}

Received: 17 January 2018; Accepted: 2 April 2018; Published: 5 April 2018

\begin{abstract}
The effects of increasing ambient ozone $\left(\mathrm{O}_{3}\right)$ concentrations on food security has become a major concern as the demand for agricultural productivity is projected to increase significantly over the next several decades. In this contribution, the responses of common soybean genotypes (AK-HARROW, PI88788, DWIGHT, PANA, and WILLIAMS82) to ambient $\mathrm{O}_{3}$ are characterized using hyperspectral data and foliar biophysical, mineral nutrient concentrations and soybean yield. Specifically, leaf reflectance spectra measured at different growth stages and canopy layers were used to examine the spectral indices that were most strongly correlated with leaf physiological status. The effects of elevated $\mathrm{O}_{3}$ on six important nutrients $(\mathrm{K}, \mathrm{Ca}, \mathrm{Mg}, \mathrm{Fe}, \mathrm{Mn}$ and $\mathrm{Cu}$ ) were evaluated by analyzing the variations in nutrient concentrations at two critical growth stages with increasing ambient $\mathrm{O}_{3}$ concentration using Partial Least Square Regression (PLSR). Lastly, the identified best spectral indices and the robust nutrient prediction models were extrapolated to the entire growth period to explore their ability to track the effects of ambient $\mathrm{O}_{3}$ concentrations on soybean physiology and nutrient uptake. The results showed that fluorescence yield $\left(\Delta F / F m^{\prime}\right)$ and photochemical quenching (qP) appear to be good indicators of soybean physiological responses to $\mathrm{O}_{3}$ stress that are echoed by the harvest index (HI). Newly identified normalized difference spectral index (NDSI) $\left[\mathrm{R}_{416}, \mathrm{R}_{2371}\right]$ always had the highest correlation $\left(R^{2}>0.6\right)$ with $\Delta F / F m^{\prime}, \mathrm{qP}$ and electron transport rate (ETR, $\mu \mathrm{mol} \mathrm{m} \mathrm{m}^{-2} \mathrm{~s}^{-1}$ ) compared to the published indices. Additionally, there were significant and broad spectral regions in visible and near infrared region that were well-correlated with $\Delta F / F m^{\prime}$ and selected NDSIs that were applicable to satellite observations. The results of nutrient modeling using PLSR explained $54-87 \%$ of the variance in nutrient concentrations, and the predicted mineral nutrient accumulation throughout the growing season reflected the responses of ozone tolerant and sensitive genotypes well. NDSI [R416, R2371] demonstrated great potential in regard to its sensitivity in tracking plant physiological responses to changing ambient $\mathrm{O}_{3}$ concentrations. The outcome of this research has potential implications for development of space-based observation of large-scale crop responses to $\mathrm{O}_{3}$ damage, as well as for biotechnological breeding efforts to improve ozone tolerance under future climate scenarios.
\end{abstract}

Keywords: hyperspectral data; ambient ozone; soybean; nutrient concentration; photochemical reflectance index (PRI); Partial Least Square Regression (PLSR)

\section{Introduction}

Lack of water availability as a result of elevated temperature and increases in ambient ozone due to climate changes have been identified as major threats to global food security [1,2]. This development is of great socio-economic importance given that global demand for agricultural production is projected 
to increase by $50 \%$ by 2050 [3]. The early detection of abiotic stress is critical to avoid yield losses in crops, which can be affected by water stress and/or photosystem damage from ambient ozone [4,5].

Excluding corn, soybean is the most-planted field crop in the US and accounts for over $50 \%$ of the world's production [6]. However, the yearly cost to the soybean crops due to the damage from ambient ozone concentrations likely exceeds $\$ 1$ billion [1] in the US and may be as high as tens of billions of dollars globally [7]. These significant costs to world agriculture are predicted to become even more costly in the next several decades with the predicted increase in tropospheric ozone [8].

As a rapid, non-destructive phenotyping technique, remote sensing has been demonstrated to be effective in monitoring plant growth inferred by leaf, canopy and ecosystem scale biophysical traits, including chlorophyll content [9], leaf area index (LAI) [10], terrestrial photosynthesis and radiation use efficiency [11], and sun-induced chlorophyll fluorescence [12]. Remote sensing-derived vegetation water content has also been widely used in mapping plant health [13-15]. Ozone damage can cause noticeable changes in one or more of these plant health indicators [16]. Even though foliar damage from ambient ozone concentrations can be visually observed [17], changes in the plant biophysical variables can ultimately decrease crop productivity, especially at the early stage of exposure to ozone, and these changes are not readily visible to the human eye. Cost-effective and timely information regarding pre-visual ozone stress on crops is critical for monitoring spatio-temporal dynamics of crop growth to guide farm management practices and crop breeding efforts.

Canopy temperature has long been used to monitor crop water stress $[18,19]$, which is based on the fact that water deficit induces a decrease in leaf stomatal conductance and transpiration rate and consequently, increases the leaf/canopy temperature. However, the relationship between the canopy temperature and stress levels is not straightforward such that the level of stomatal conductance interacts with evaporative demand as well as vegetation water content [20]. Additionally, remotely sensed canopy temperature is confounded with shadow and background soil temperature variation [21], which makes plant health detection particularly challenging in heterogeneous, open tree canopy environments. In recent years, a growing body of studies has demonstrated that chlorophyll fluorescence and the photochemical reflectance index (PRI) can be used as early indicators of plant health [20,22].

Chlorophyll fluorescence is closely related to the function of photosystem II, stomatal conductance and other photosystem de-excitation pathways [23], providing a direct approach for the early detection of vegetation stress associated with photosynthetic functionality, before chlorophyll reduction occurs [24]. The PRI reflects the epoxidation state of the xanthophyll cycle pigments and photosynthetic efficiency [25], indicating plant physiological status. On the other hand, narrow-band red-edge indices that are sensitive to chlorophyll concentrations have also been proven to be effective in early stress detection [26]. For example, [27-29] found that the ratio between red-edge (694 $\mathrm{nm}$ ) and near infrared $(760 \mathrm{~nm})$ was superior to thermal imagery in early stress detection, which allowed identification of stress about two weeks prior to the signs of visual damage. The reason for the $694 / 760 \mathrm{~nm}$ ratio being most effective in pre-visual stress detection is probably due to the fact that these wavelengths correspond to two important physiological measures of plant water stress-chlorophyll fluorescence and vegetation water content [30]. It is worth noting, however, that translating chlorophyll fluorescence data directly to plant physiology (e.g., photosynthesis) is challenging because fluorescence, photosynthesis and non-photochemical quenching are closely connected. For example, (1) they compete for the use of absorbed light, and (2) the relationship between chlorophyll fluorescence and photosynthesis is positive under stress and negative for no-stress conditions [31]. In open field environments, this can change depending on the time of the day and changes in light conditions.

Few studies of fluorescence, PRI and red-edge indices have been conducted to study the impact of ozone on crops in an open air field environment with remotely sensed data. Furthermore, only a few authors have attempted to assess ozone damage at leaf [32] and canopy [33] scales using PRI. While obvious decreases in chlorophyll, nitrogen content and therefore, crop yield were observed with elevated ozone, Ainsworth et al. [34] found no effect of ozone on photosynthetic capacity, which might be attributed to insufficient temporal sampling of spectral measurements. Thus, there is a strong 
need to compare the performances of fluorescence, PRI and red-edge indices on characterizing crop responses to ambient ozone concentrations in a field growth environment. Although the $531 \mathrm{~nm}$ wavelength has been accepted as the best PRI measurement band, there has been no consensus in literature on the use of the PRI reference band (570 nm). For example, $512 \mathrm{~nm}$ [35], $515 \mathrm{~nm}$ [20] and $586 \mathrm{~nm}$ [22] have all been reported as the "best" reference band in recent years, emphasizing the need for additional work to determine the ideal PRI reference band. There have been numerous studies focused on macronutrient effects of abiotic stress, including salt stress [36], heavy metal pollution [37], low temperature [38] and water stress [39,40]; no studies reported mineral nutrient accumulation in plant tissues in response to ambient ozone concentrations.

While long time exposure to water or salt stress may change the flowering time and reduce seed production, short term stress effects can be mitigated by appropriate farm management and irrigation practices before permanent damage occurs. However, foliar injury on plants from ozone can be permanent and very difficult to be mitigated. Efforts should focus on reducing ambient ozone concentration and developing ozone-tolerant crop breeds. The objectives of this study are (1) to determine the responses of soybean cultivars to ambient ozone on soybean crops in open agricultural ecosystems using hyperspectral data and plant mineral nutrient concentration, and (2) to develop remote sensing methods that improve early ozone stress detection for proactive planning with respect to food insecurity.

\section{Materials}

\subsection{Experimental Design and Abiotic Conditions}

The experimental site was located in Maryland Heights, Missouri, USA $\left(38^{\circ} 42^{\prime} 48.10^{\prime \prime} \mathrm{N}\right.$, $90^{\circ} 30^{\prime} 22.81^{\prime \prime} \mathrm{W}$ ). The site was $4 \times 4 \mathrm{~m}$ in dimension with five $0.76 \mathrm{~m}$ spaced rows, and soil type was Peers Silk Loam soil. On 23 April 2014, 100 seeds $(0.015 \mathrm{~kg})$ were sown in each row, corresponding to five soybean genotypes, including AK-HARROW, PI88788, DWIGHT, PANA, and WILLIAMS82. AK-HARROW and PI88788 were found to be relatively sensitive [41], while DWIGHT, PANA and WILLIAMS82 were identified as relatively tolerant to ozone [4,5]. The number of plants were 55, 48, 71, 65 and 56 for AK-HARROW, PI88788, DWIGHT, PANA, and WILLIAMS82, respectively. The flower color was white for AK-HARROW and WILLIAMS82, purple-pick for DWIGHT and PANA, and purple for PI88788. All abiotic conditions were the same for the study organisms during the experiment. Monthly accumulated rainfall was $177 \mathrm{~mm}$ in June, $28 \mathrm{~mm}$ in July, $124 \mathrm{~mm}$ in August, and $166 \mathrm{~mm}$ in September. It was assumed that nutrient variations among the different soybean genotypes were most likely dominated by their tolerance to elevated ambient ozone concentration. However, the contribution of fertilizers and rainfall was not taken into account. Ozone-damaged leaves generally show tiny light-tan irregular spots, bronzing of small darkly pigmented areas, and reddening [42], which started to emerge in early August.

\subsection{Hyperspectral Reflectance and Leaf Area Index Measurements}

All of the measurements were made under clear-sky conditions between 10:00 a.m. to 2:00 p.m. once per week during the growing season of the soybean genotypes. Leaf reflectance spectra were collected on three leaves from six plants $(n=6)$ within each genotype (row). The three leaves were the third trifold from the top, middle leaf and the bottom leaf down the canopy, representing three canopy layers based on documented agronomic canopy layer standards $[43,44]$. We used high resolution full range PSR-3500 (Portable Spectroradiometer, Spectral Revolution, Inc., Lawrence, MA, USA). The wavelength range of PSR-3500 is $350-2500 \mathrm{~nm}$ with a resolution of $3.5 \mathrm{~nm}$ in the $350-1000 \mathrm{~nm}$ range, $10 \mathrm{~nm}$ in the $1000-1900 \mathrm{~nm}$ range and $7 \mathrm{~nm}$ in the $1900-2500 \mathrm{~nm}$ range. A reference spectrum was taken from a 99\% Spectralon calibration panel (Labsphere, Inc., North Sutton, NH, USA) before target measurement and repeated for every other five measurements to re-adjust the baseline to account for any change in illumination. Then, a leaf clip with a bifurcated fiber-optic connected to both the 
device and a 5-watt tungsten halogen lamp light source was used to record leaf reflectance readings with a black background. The PSR-3500 was configured to automatically average 40 scans for each sampling. The raw spectra bandwidth was interpolated to $1 \mathrm{~nm}$ for further analysis.

Leaf area index (LAI) was measured throughout the growing season using the LAI-2200C Plant Canopy Analyzer (LI-COR Inc., Lincoln, NE, USA). Two above canopy readings taken at the beginning and end of the transects were paired by three below canopy readings along the transect crossing two consecutive crop rows. The sensor view direction with $45^{\circ}$ view cap was positioned looking along the row (view direction is parallel to the row) in the first transect and looking across (perpendicular to) the row in the next transect. Extra sky radiation measurements were taken for scattering corrections.

\subsection{Gas Exchange and Fluorescence Measurements}

Simultaneous measurements of individual gas exchange and Chl fluorescence variables, including photosynthesis $\left(\mu \mathrm{mol} \mathrm{CO} \mathrm{CO}^{-2} \mathrm{~s}^{-1}\right)$, stomatal conductance $\left(\mathrm{mol} \mathrm{H}_{2} \mathrm{O} \mathrm{m}^{-2} \mathrm{~s}^{-1}\right)$ and steady-state fluorescence were made on 13 August 2014 using LI-6400XT Portable Photosynthesis System installed with a pulse amplitude-modulated leaf chamber fluorometer (Li-Cor, Inc., Lincoln, NE, USA) (Table 1). The measurements were taken on the third leaf from the top of the six plants used for leaf reflectance within each genotype. The measurement was made on this day because visual signs of foliar ozone damage occurred during this growth stage (Figure 1). The chlorophyll fluorescence yield, which measures the instantaneous photochemical efficiency of photosystem II (PSII) was determined by $\Delta F / F m^{\prime}=\left(F m^{\prime}-F s\right) / F m^{\prime}[45]$, where $F m^{\prime}$ is the maximum fluorescence yield under environmental conditions (light adapted), and $F s$ is the steady-state fluorescence (light adapted) measured before the saturation pulse.

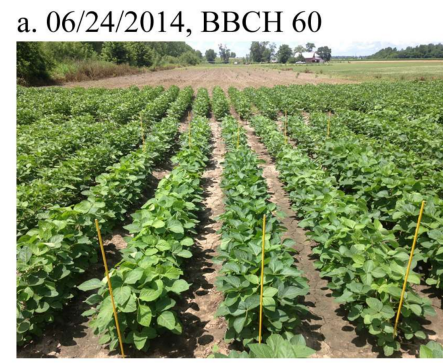

b. $07 / 02 / 2014$, BBCH 65

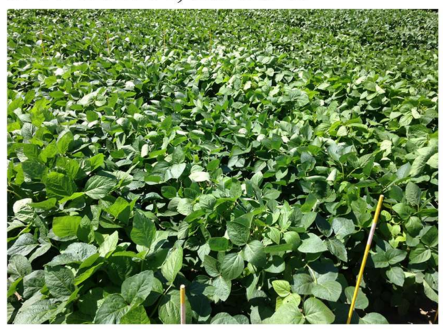

e. $07 / 25 / 2014$, BBCH 73

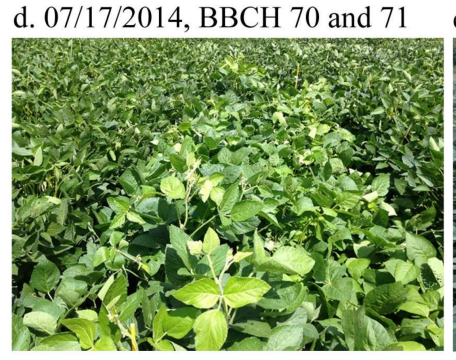

j. 08/29/2014, BBCH 80

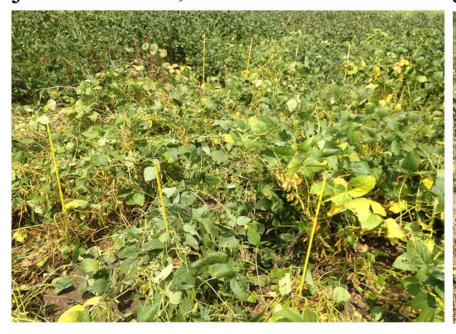

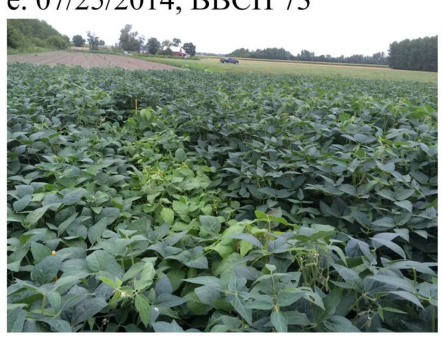

g. 09/19/2014, BBCH 89/97

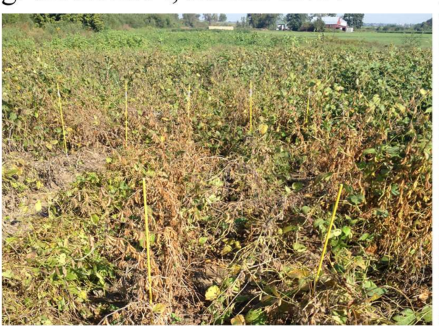

c. $07 / 09 / 2014$, BBCH 69

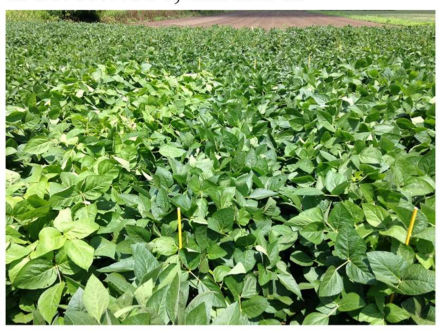

f. $08 / 12 / 2014$, BBCH 79

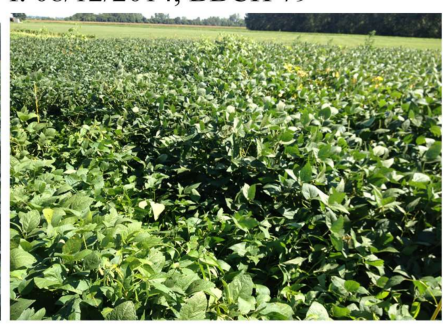

h. Ozone damage on leaves

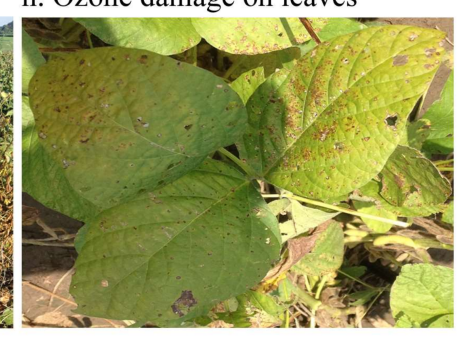

Figure 1. Phenological stages of soybean genotypes during the growth period: $(\mathbf{a}-\mathbf{g})$ the Biologische Bundesanstalt, Bundessortenamt and Chemical (BBCH) stages [46]; (h) leaves showing ozone damage which is becoming visible after BBCH 79. 
Table 1. Leaf gas exchange and $\mathrm{Chl}$ a fluorescence measured for the different genotypes, under conditions of light intensity $=1000 \mu \mathrm{mol} \mathrm{m}{ }^{-2} \mathrm{~s}^{-1}, \mathrm{CO}_{2}=400 \mu \mathrm{mol}$ $\mathrm{CO}_{2} \mathrm{~mol}^{-1}$, light pulse for Chl fluorescence $\sim 8000 \mu \mathrm{mol} \mathrm{m}{ }^{-2} \mathrm{~s}^{-1}$, Tblock = ambient $\mathrm{T}$, air flow $=300 \mu \mathrm{mol} \mathrm{s}{ }^{-1}$. Values are means $\pm \mathrm{SD}, \mathrm{n}=$ number of measurements for each genotype.

\begin{tabular}{|c|c|c|c|c|c|c|c|c|}
\hline $\begin{array}{ll}\text { Leaf Physiology } \\
\end{array}$ & $\mathrm{F}_{\mathrm{s}}$ & $\Delta F / F m^{\prime}$ & $\mathrm{G}_{\mathrm{s}}$ & $\mathbf{P}_{\mathbf{n}}$ & $\mathbf{q P}$ & NPQ & ETR & $\mathbf{T}_{\text {leaf }}$ \\
\hline AK-HARROW $(n=6)$ & $912 \pm 61$ & $0.33 \pm 0.09$ & $0.20 \pm 0.03$ & $25.7 \pm 1.7$ & $0.6 \pm 0.14$ & $4.6 \pm 0.9$ & $154 \pm 23.7$ & $29.7 \pm 1.1$ \\
\hline PI88788 $(n=6)$ & $1017 \pm 187$ & $0.13 \pm 0.02$ & $0.17 \pm 0.11$ & $20.8 \pm 5.6$ & $0.29 \pm 0.06$ & $5.7 \pm 1.1$ & $97 \pm 21.1$ & $33.4 \pm 1.0$ \\
\hline PANA $(n=6)$ & $897 \pm 64$ & $0.17 \pm 0.03$ & $0.08 \pm 0.11$ & $16.5 \pm 8.3$ & $0.39 \pm 0.6$ & $6.1 \pm 0.4$ & $130 \pm 26.5$ & $36.4 \pm 1.6$ \\
\hline WILLIAMS82 $(n=6)$ & $838 \pm 59$ & $0.18 \pm 0.04$ & $0.13 \pm 0.09$ & $22.5 \pm 7.8$ & $0.42 \pm 0.7$ & $6.3 \pm 0.7$ & $141 \pm 31.8$ & $34.8 \pm 1.3$ \\
\hline
\end{tabular}

Steady-state fluorescence $\left(\mathrm{F}_{\mathrm{s}}\right)$, fluorescence yield $\left(\Delta F / F m^{\prime}\right)$, instantaneous stomatal conductance $\left(\mathrm{G}_{\mathrm{s}}, \mathrm{mol} \mathrm{H}_{2} \mathrm{O} \mathrm{m}^{-2} \mathrm{~s}^{-1}\right)$, net assimilation $\left(\mathrm{P}_{\mathrm{n}}, \mu \mathrm{mol} \mathrm{CO}_{2} \mathrm{~m}^{-2} \mathrm{~s}^{-1}\right)$, photochemical $(\mathrm{qP})$ and

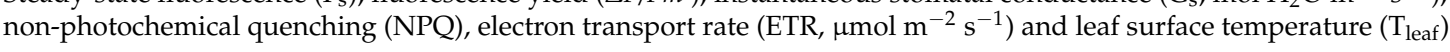




\subsection{Foliar Nutrient Concentration and Yield Determination}

A total of 180 leaves, used for leaf reflectance measurements on both 17 July and 13 August 2014, were destructively collected and sent to Danforth Plant Science Center located in St. Louis, Missouri, USA for the analysis of nutrient concentrations using ion coupled plasma mass spectroscopy (ICP-MS, Perkin-Elmer SCIEX). The leaf samples for the ICP-MS were carried out following the methods described in [47]. $\mathrm{K}, \mathrm{Ca}, \mathrm{Mg}, \mathrm{Fe}, \mathrm{Mn}$ and $\mathrm{Cu}$ are the important elements for plant photosynthesis and gas exchange concentration [48]. Therefore, we focused our analysis on the aforementioned six nutrient elements out of the 19 elements that were measured in the lab.

For each soybean genotype, the seed yield $(\mathrm{kg} / \mathrm{ha}$ ) and biomass were obtained using an Almaco small bundle thresher (Almaco, Nevada, IA, USA) on 1 October 2014. Threshed biomass with the soybean pods retained over a row length of $1.21 \mathrm{~m}$ and a width of $0.76 \mathrm{~m}$ was weighted to determine above-ground biomass. Harvest index (HI) was computed using the ratio between seed yield (g) and above-ground dry biomass (g) [49].

\subsection{Ozone Data}

Ozone measurements were obtained from a 2B Technologies ozone sensor (Model 106-L) located $\sim 22 \mathrm{~km}$ southwest of the experimental site at one of the St. Louis Ozone Gardens located in Forest Park [41,50]. This instrument has operated nearly continuously since 2012 and is designed for the measurement of ambient ozone concentration down to a very low concentration. The instrument has been designated by the Environmental Protection Agency (EPA) as a Federal Equivalent Method (FEM) for monitoring compliance with the US Clean Air Act (EQOA-0914-218). The data were readily available from the instrument's data archive (http:/ / go3project.com), which has 15-min resolution. Analyses of these data have been shown to be consistent with archived data at Missouri's Department of Natural Resources (DNR), where the archived time resolution is $1 \mathrm{~h}$. None of the DNR's monitoring stations is significantly closer to the experimental site than the location of the one in the Ozone Garden used for this study.

\section{Methods}

\subsection{Statistical Analysis}

Among the five soybean genotypes, statistics were performed on the genotype means of nutrient concentrations to investigate the effect of early (17 July 2014) and late (13 August 2014) growth stage on nutrient variability. The day of the year was considered to be a fixed effect. A multiple comparisons test using Bonferroni adjusted $t$ test, was carried out in order to determine which pairs of genotype had differing means.

\subsection{Finding the Best Spectral Regions to Map Fluorescence Yield}

One of the methods to find the link between biophysiological variables and spectral information is building indices in the form of mathematical formulae integrating spectral wavebands. In this section, we describe how we identified the wavelengths and/or normalized indices (Equation (1)) that are capable of estimating fluorescence yield, a sensitive indicator of crop health and ozone damage. We used the data collected on both 17 July and 13 August 2014 to develop the index. Once developed, the index has the potential to track plant biophysiological changes throughout the growth period.

We used the normalized difference spectral index (NDSI) to identify optimal wavelengths and/or indices. The NDSI is defined as:

$$
\operatorname{NDSI}(i, j)=\frac{R_{i}-R_{j}}{R_{i}+R_{i}}
$$

where $R$ is the reflectance value and subscripts are wavelengths in nm.

NDSI were calculated for the leaf level hyperspectral reflectance spectra using all possible combinations of available bands ( $i$ and $j \mathrm{~nm}$ ). Linear relationships between in-situ fluorescence yield 
measurements and NDSIs were examined, and raster maps of coefficient of determination $\left(R^{2}\right)$ and corresponding $p$-values were generated. Raster maps of NDSI allowed the evaluation of the different band combinations and the selection of a sensitive NDSI for crop health and ozone damage detection.

The performance our indices was then compared with previously published indices from the relevant literature as shown in Table 2.

Table 2. Spectral indices used in this study.

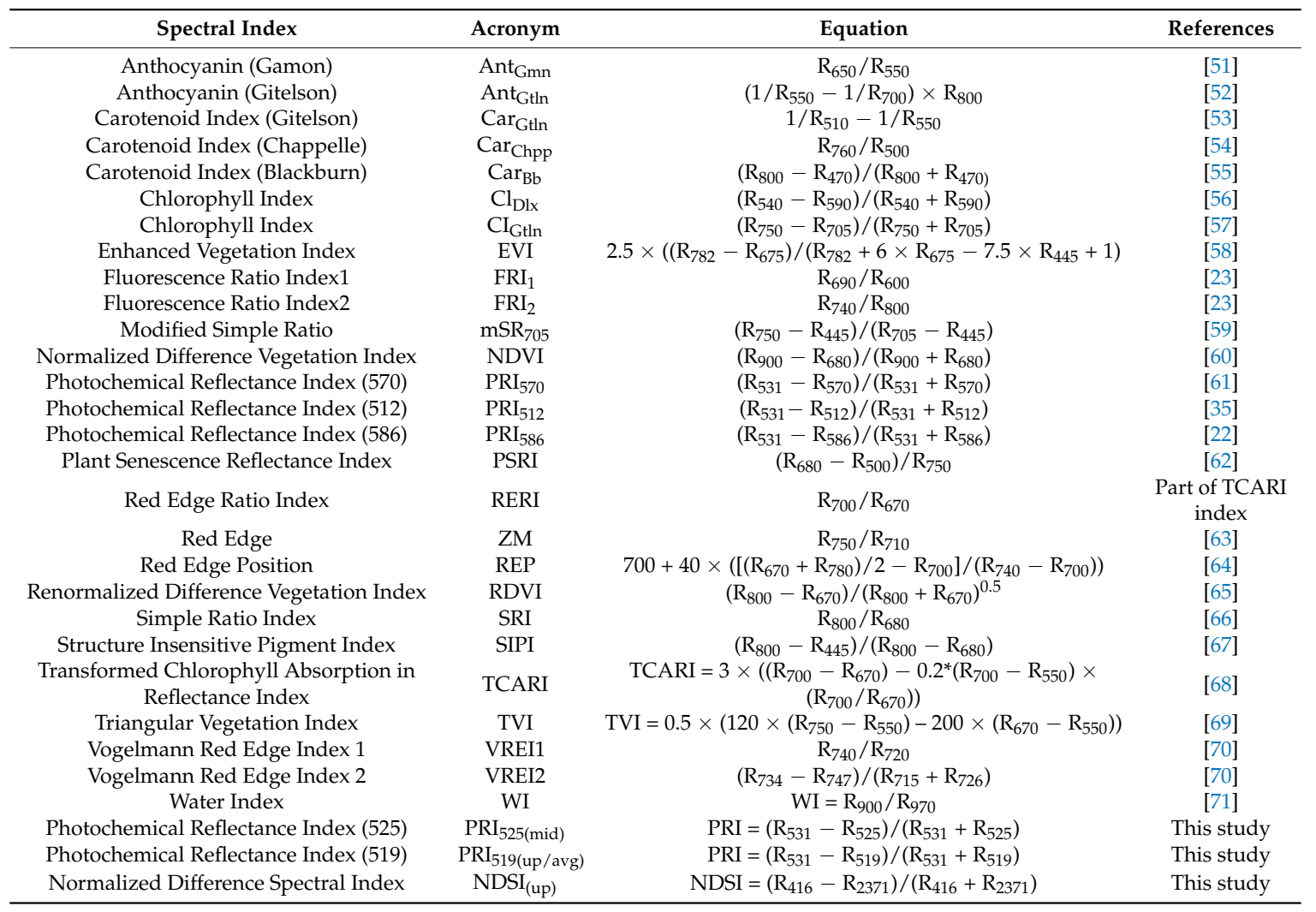

\subsection{Partial Least Squares Regression (PLSR) Modeling}

The variation in nutrient concentration within five soybean genotypes was analyzed. The variation was calculated for major nutrients by subtracting the concentration values on 17 July 2014 from the concentration values on 13 August 2014.

The development of mineral nutrient prediction models was conducted with the Partial Least Square (PLS) package in R statistical software [72]. In order to increase the sample size and model robustness, leaf nutrient concentrations and reflectance data from two dates were combined to develop universal models using partial least squares regression (PLSR). To select the optimum number of latent variables (LV) and avoid overfitting, we calculated the minimum root mean squared error of cross-validation (RMSE-CV) (Equation (2)) by the iterative leave-one-out method and relative RMSE-CV (RMSE\%) (Equation (3)). For each nutrient predictive model, the coefficient of determination $\left(R^{2}\right)$ between the predicted and observed parameters was calculated. $R^{2}$ indicates the impact of each independent variable on the dependent variable - the greater the $R^{2}$ value, the greater the impact on the dependent variable of the response variable. $R M S E-C V$ was calculated by the following equations:

$$
\begin{aligned}
R M S E-C V & =\sqrt{\frac{1}{n} \sum_{i=1}^{n}\left(y_{p}-y_{i}\right)^{2}} \\
R M S E \% & =\frac{R M S E-C V}{\hat{y}}
\end{aligned}
$$


where $n$ is the number of samples in test set, $y_{p}$ and $y_{i}$ are the predicted and measured nutrient concentrations of the sample $i . \hat{y}$ is the mean of the measured nutrient concentration.

\section{Results and Discussion}

\subsection{Leaf Gas Exchange and Yield}

Figure 2 shows the genotype-average fluorescence yield $\left(\Delta F / F m^{\prime}\right)$, photochemical quenching $(\mathrm{qP})$ and photosynthetic rate $\left(\mu \mathrm{mol} \mathrm{CO} \mathrm{C}^{-2} \mathrm{~s}^{-1}\right)$ measured on 13 August 2014 along with the harvest index and crop yield. The highest and lowest fluorescence yields were recorded with AK-HARROW and PI88788, respectively, and the same trend was true for the photochemical quenching values of the genotypes. The second highest values of $\Delta F / F m^{\prime}$ and $\mathrm{qP}$ were found with WILLIAMS82, which was followed by PANA and DWIGHT. The highest yield was obtained from DWIGHT, and the second-highest yield from WILLIAMS82, which was closely followed by AK-HARROW and PANA. The harvested yield was the lowest for PI88788.

(a)

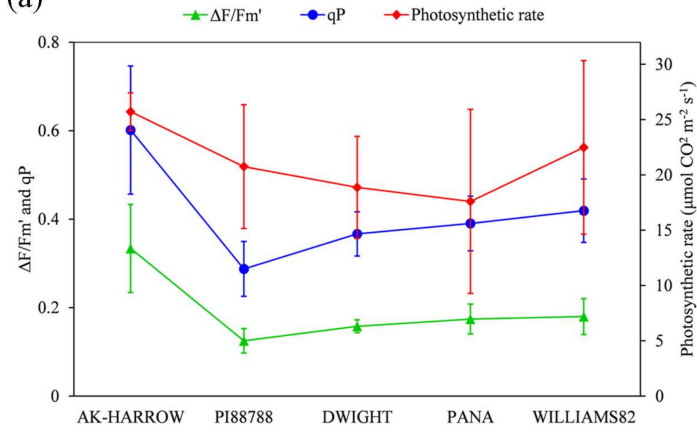

(b)

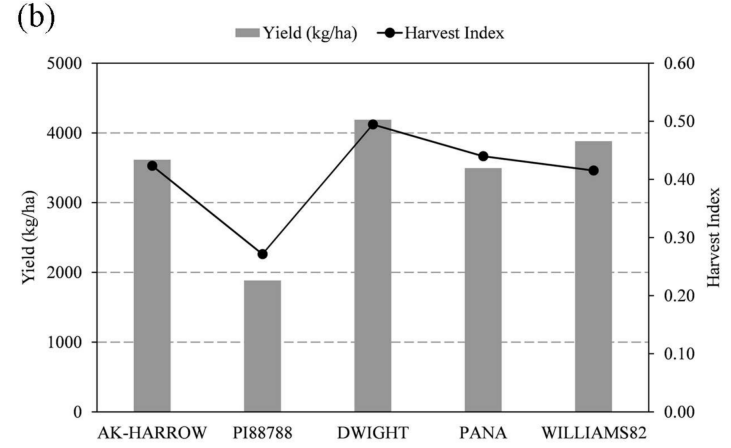

Figure 2. Genotype-average fluorescence yields $\left(\Delta F / F m^{\prime}\right)$, photochemical quenching (qP) and photosynthetic rates $\left(\mu \mathrm{mol} \mathrm{CO} \mathrm{Cm}^{-2} \mathrm{~s}^{-1}\right.$ ) measured on 13 August 2014, along with harvest indexes and crop yields. The lowest crop yield, harvested from PI88788, corresponds to the lowest values of $\Delta F / F m^{\prime}$ and $\mathrm{qP}$. Ozone tolerant genotypes produced overall higher yields than the sensitive genotypes.

$\Delta F / F m^{\prime}$ estimates the light use efficiency of plant PSII for electron transport. Therefore, $\Delta F / F m^{\prime}$ reflects the ability of a plant to tolerate environmental stresses and the extent to which those stresses have damaged the photosynthesis [31]. Chlorophyll fluorescence emission, photochemical quenching (light energy is harvested for photosynthesis) and non-photochemical quenching (excess energy is dissipated as heat) occur in competition [31]. When a plant is exposed to abiotic stress, light energy used for photochemistry decreases due to protective closure of the PSII apparatus, which may increase in steady-state fluorescence and/or non-photochemical quenching. In general, increased steady-state fluorescence is an indication of decreased $\Delta F / F m^{\prime}$ and therefore, is an early sign of abiotic stress. $\Delta F / F m^{\prime}$ is positively correlated with $\mathrm{qP}$ and photosynthetic rate. This is evident in Figure 2 with a minor exception of the photosynthetic rate such that one would expect the lowest photosynthetic rate for PI88788 instead of PANA. It is worth noting that plant tissues tend to shift toward increasing heat production at the initial and intermediate states of stress [12]. This may imply that much of the excess energy absorbed by PANA is being dissipated as heat rather than steady-state fluorescence causing the higher $\Delta F / F m^{\prime}$ and lower photosynthetic rate.

Harvest index, calculated as the ratio of seed yield by the total pounds of above ground biomass, is often used as a measure of reproductive efficiency. Harvest index reflects breeding achievements and is affected by stress and/or crop management practices during crop reproductive development [73]. The low-high pattern of the harvest index among the soybean genotypes was surprisingly similar to that of both $\Delta F / F m^{\prime}$ and $\mathrm{qP}$, given the fact that gas exchange measurements were a snapshot of plant physiological status on a specific date of measurement, while harvest index was a reflection of crop growth throughout the entire growth cycle. This was supported by our field observations that the 
study organisms had experienced different degrees of ozone damage by 13 August 2014 depending on their tolerance to ambient ozone concentrations; this confirms that the measurements made on this day were reflective of overall crop health and potential harvest yield.

\subsection{Mineral Nutrient Uptake Rate}

A significant number of publications have reported nutrient variations and changes in mineral nutrient uptake rate in plants due to water, salt stress and cold temperature stress $[38,74,75]$. However, to our best knowledge, very few researchers have focused on ion/nutrient effects of ambient ozone concentrations.

Mineral concentration was very different among the five soybean genotypes at the early and late growth stages. One-way ANOVA test shows that $\mathrm{K}$ and Fe are not statistically significant among the soybean genotypes at the early date (17 July 2014 (Figure 3)) which means there were no significant differences in $\mathrm{K}$ and Fe concentrations across the five soybean genotypes $(\alpha<0.05)$. Data from 13 August 2014 (Figure 4) shows that there were no significant differences in Ca and Fe concentrations among the five different soybean genotypes $(\alpha<0.05)$. This may imply that Fe is not a sensitive indicator of ozone stress, and the other elements may be used to characterize the ozone effects at different plant phenological stages. In contrast, $\mathrm{Cu}, \mathrm{Mg}$ and $\mathrm{Mn}$ variations were consistently significant in both the early and late growth stages and $\mathrm{K}$ variation was significant at the late growth stage in regard to increased ozone damage, which may provide useful insight into characterizing plant response to ambient ozone concentration.

Figure 5 shows the percent change in mineral nutrient accumulation between the 17 July and 13 August 2014 observation dates, which was calculated by dividing the mineral nutrient accumulation difference between 17 July and 13 August over the measurement taken on 13 August. The uptake rates of all mineral nutrients were significantly affected by the increasing ozone concentration. Previous studies have demonstrated that AK-HARROW and PI88788 are relatively ozone-sensitive genotypes compared to DWIGHT, PANA and WILLIAMS82 [41]. The highest increase in tissue Ca was found with PI88788, which was followed by AK-HARROW, DWIGHT and WILLIAMS82. PANA showed the smallest increase in Ca, which suggests PI88788 and PANA are the most and least ozone-sensitive genotypes among the study organisms. Ca is a crucial regulator of plant growth and development, which has been implicated in an increase in plant tissues' responses to a number of abiotic stresses, including low temperature, osmotic stress, heat, oxidative stress, anoxia, and mechanical perturbation [38]. It could be possible, however, that a prolonged elevated cellular concentration of $\mathrm{Ca}$ is detrimental to plant cells [38].

As an essential nutrient, $\mathrm{K}$ plays an important role in plant biochemical and physiological processes, e.g., photosynthesis and respiration, that influence plant growth and metabolism [76]. K showed very distinct decreasing and increasing trends between the two groups. The percent changes in leaf tissue K were $-9.7 \%$ and $-3.5 \%$ for AK-HARROW and PI88788 genotypes and 29.9\%, 34.9\% and $20.8 \%$ for DWIGHT, PANA and WILLIAMS82, respectively. Plant growth under stressed conditions is restricted by osmotic effects and toxic effects of ions, which results in lower nutrient uptake and inhibits the translocation of $\mathrm{K}$ [76]. The striking decrease-increase trend of $\mathrm{K}$ tissue concentration between the two groups of soybean genotypes supports the argument that AK-HARROW and PI88788 are less tolerant to ozone damage than the other genotypes. It should be noted that $\mathrm{Mg}$ and $\mathrm{Mn}$ changes were opposite to the $\mathrm{K}$ variation among the genotypes with a minor exception that both PANA and WILLLIAMS82 showed slight decreases in Mg (-6.1\%) and Mn (-8.6\%). K regulates the translocation of photosynthates into sink organs, maintenance of turgor pressure, activation of enzymes, and reduces excess uptake of ions when plants are exposed to abiotic stress [77]. The higher concentrations of $\mathrm{Mg}$ and $\mathrm{Mn}$ in ozone-sensitive genotypes, especially in PI88788, may be associated with decreased $\mathrm{K}$ concentrations in these genotypes. Although it is not possible to establish a direct one-to-one relationship, the decrease-increase pattern of nutrient concentrations among the study organisms is arguably consistent with yield (Figure 2). 

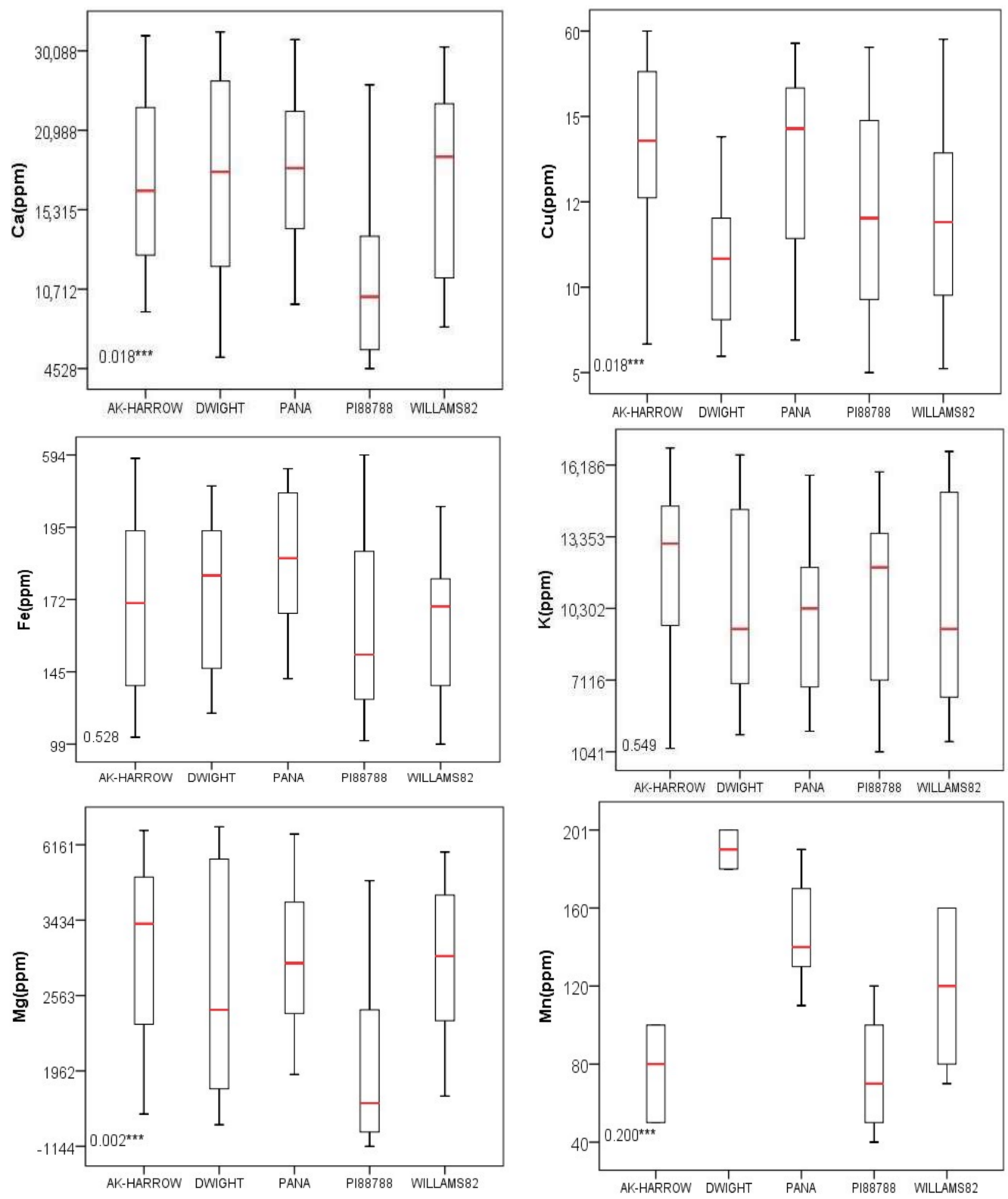

Figure 3. Variation in mineral nutrient concentration among soybean species on 17 July 2014. Whiskers indicate the 5 th and 95 th percentiles. Solid lines inside the box represent the median; the colored areas represent the 25 th and 75 th percentiles. The significant level is also shown $(* * *<0.05)$. The results indicate that $\mathrm{K}$ and $\mathrm{Fe}$ are less significant among soybean cultivars at the early growth stage. When plants were not yet exposed to significant ozone damage, on 17 July 2014, foliar concentrations of Ca, $\mathrm{Fe}, \mathrm{Mn}$ were lower and K concentration was higher for ozone-sensitive cultivars AK-HARROW and PI88788 than the rest of the cultivars.

Overall, the increase in foliar concentrations of $\mathrm{Ca}, \mathrm{Mg}$ and $\mathrm{Mn}$, and the decrease of $\mathrm{K}$ among ozone-sensitive genotypes was similar to the observations in salt stressed plants [78], indicating possible similarities in nutrient uptake and stomatal behaviors between ozone and salt stress mechanisms. However, our work showed some unique observations of plant responses to ozone stress, which were evident from the differences between leaf tissue mineral nutrient accumulation among the ozone-sensitive and tolerant genotypes. Moreover, except for WILLLIAMS82, the difference in $\mathrm{Cu}$ concentration between the two measurement dates was similar to that of $\mathrm{K}$, i.e., decreased in ozone-sensitive genotypes and increased in ozone-tolerant genotypes, respectively. Similarly, mixed $\mathrm{Cu}$ signals due to salt stress has been reported by other studies involving soybean [36] and canola [79] 
genotypes. However, the majority of publications have confirmed that salt stress mostly reduces the leaf tissue $\mathrm{Cu}$ concentration in less stress-tolerant plants [78], and the foliar $\mathrm{Cu}$ concentration can increase until a critical stress level is reached, before decreasing beyond the critical level [80]. The decrease in foliar $\mathrm{Cu}$ concentration in AK-HARROW, PI88788 and WILLLIAMS82 on 13 August 2014 may be attributed to their stress tolerance limits, which might have already been reached. In contrast, the severity of ozone stress was not yet inhibitory for DWIGHT and PANA in regard to the uptake of $\mathrm{Cu}$ and other nutrients.
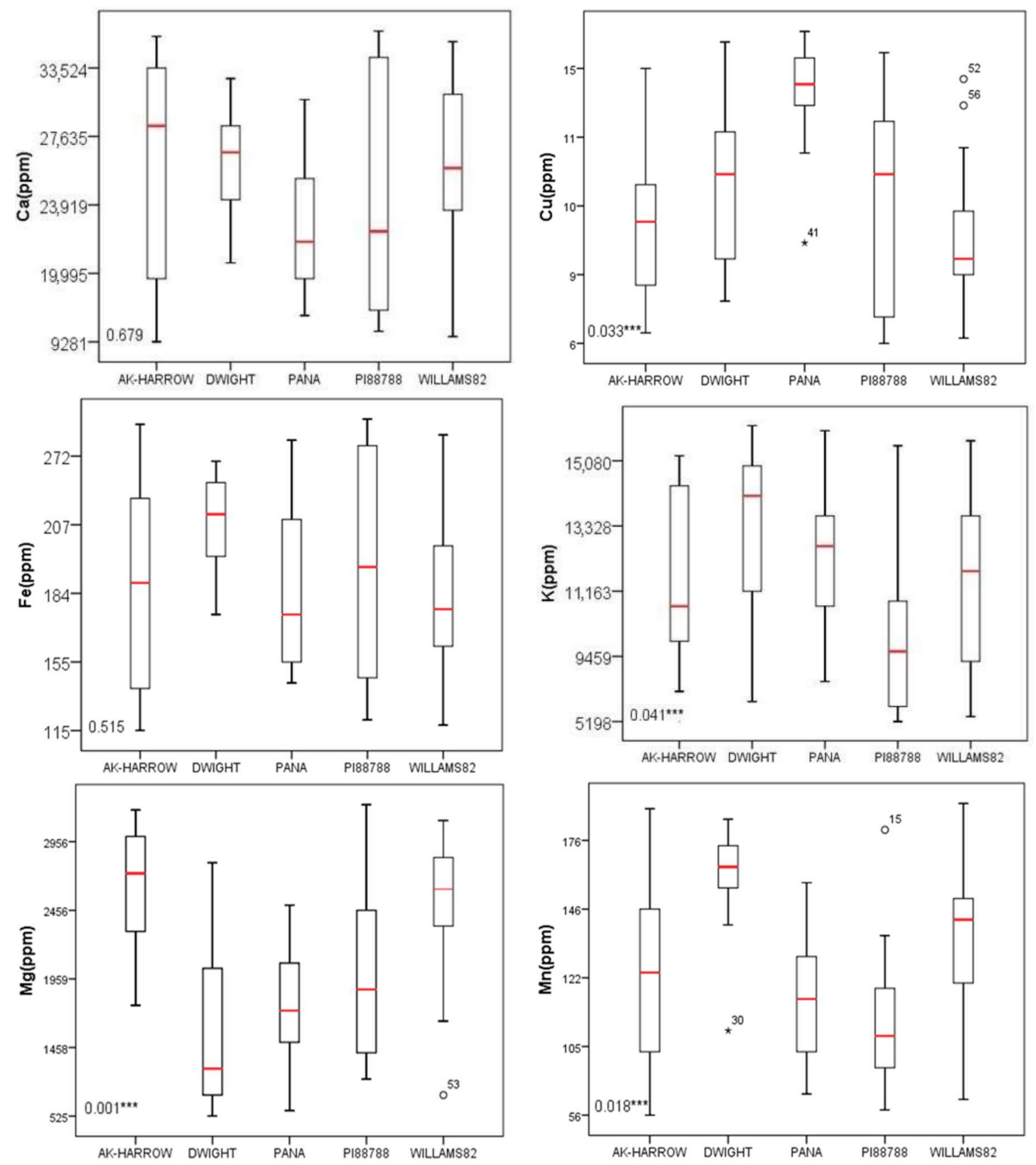

Figure 4. Variation in mineral nutrient concentration within soybean genotypes on 13 August 2014. Whiskers indicate the 5th and 95th percentiles. Solid lines inside the box represent the median; the colored areas represent the 25 th and 75 th percentiles. The significant level is also shown ${ }^{* * *} p$ $<0.05)$. At this growth stage, $\mathrm{Ca}$ and Fe variations are less significantly different among soybean genotypes. When plants were exposed to significant ozone damage on 13 August 2014, the foliar concentrations of $\mathrm{K}$ and $\mathrm{Mn}$ were lower and the $\mathrm{Fe}, \mathrm{Mg}$ concentrations were higher for ozone-sensitive genotypes AK-HARROW and PI88788 than for the rest of the genotypes. 


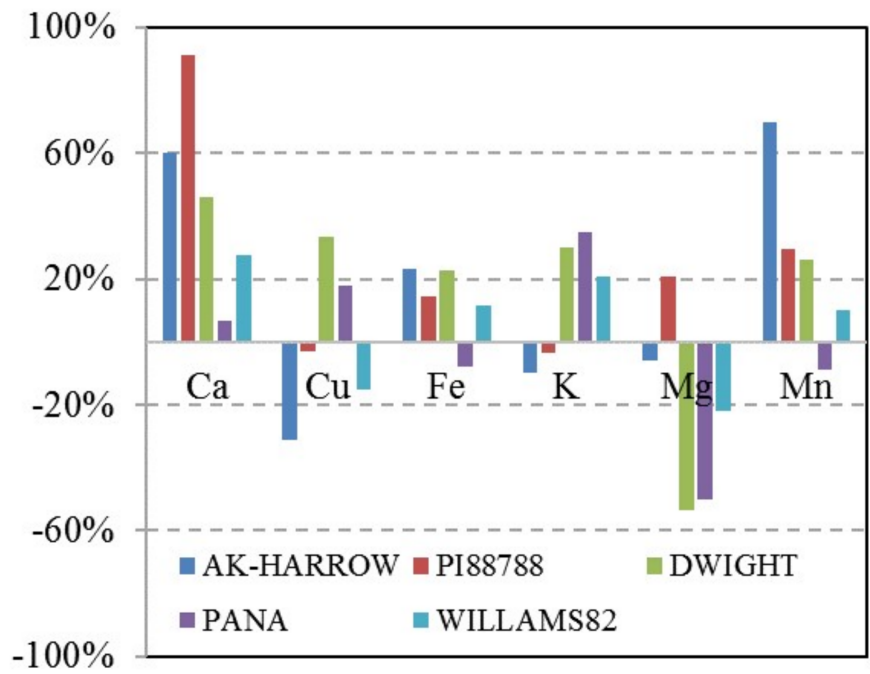

Figure 5. Variation in mineral nutrient concentration within five soybean genotypes. Differences were calculated for major elements by subtracting the concentration values on 13 August 2014 from measurements on 17 July 2014.

\subsection{Best Spectral Regions Correlated with Fluorescence Yield}

Figure $6 \mathrm{a}, \mathrm{b}$ present the heat map of $R^{2}$ and $p$-values between the fluorescence yield $\left(\Delta F / F m^{\prime}\right)$ and the normalized difference spectral index (NDSI $\left[R_{i}, R_{j}\right]$ ) using complete spectrum reflectance combinations of two wavebands at $R_{i}$ and $R_{j}$. NDSI is defined as $\left(R_{i}-R_{j}\right) /\left(R_{i}+R_{j}\right)$. As shown in Figure $6 \mathrm{c}$, there were six significant spectral regions $(\mathrm{A}, \mathrm{B}, \mathrm{C}, \mathrm{D}, \mathrm{E}$ and $\mathrm{F})$, where $R^{2}$ ranged between 0.36 and 0.64 . The hotspot regions, C, D, E and F, within NIR, and the shortwave infrared (SWIR) bands tended to have higher $R^{2}\left(0.42<R^{2}<0.64\right)$ compared to the regions, $\mathrm{A}$ and $\mathrm{B}$, which only included visible and red-edge bands. $\Delta F / F m^{\prime}$ had the highest $R^{2}$ of $0.64(p<0.001$, RMSE $=0.05)$ with NDSI $\left[R_{416}, R_{2371}\right]$ that was found in region $D$. Blue and red portions of photosynthetically active radiation (400-700 nm) more efficiently excite chlorophyll than green portions [81]. Compared to red light, blue light induces stronger chlorophyll fluorescence emission, which may be attributed to the fact that (1) blue light is strongly absorbed by photosynthetic pigments (chlorophyll ab and carotenoids), (2) has low penetration ability, and (3) blue light induced fluorescence is mostly from the upper leaf half, rather than from subjected reabsorption [82]. This could be the reason for the selection of blue band $419 \mathrm{~nm}$ as a measurement band, while the SWIR band was used as a reference band as it is not affected by photosynthetic pigments. Nevertheless, due to the lower signal to noise ratio (SNR) of detectors caused by physical constraints, wavelengths in the SWIR spectral region may have low SNRs. Satellite remote sensing requires comprehensive atmospheric correction to reduce the influence of atmospheric water vapor [14]. Hotspot areas were located in near infrared (NIR) bands. $\Delta F / F m^{\prime}$ was most correlated with NDSI $\left[R_{523}, R_{533}\right]\left(R^{2}=0.35, p<0.0005\right.$, RMSE $\left.=0.08\right)$ in region A and with NDSI $\left[R_{613}, R_{614}\right]\left(R^{2}=0.36, p<0.0005\right.$, RMSE $\left.=0.07\right)$ in region $B$. The extent of these significant regions (510-590 nm and 450-550 nm for region A, 560-710 nm and 550-670 nm for region B) is spectrally wide, covering visible and red-edge regions. Visible and red-edge spectral regions are known to be sensitive to small changes in light absorbing pigments and leaf cell structure $[29,83]$. Further, in comparison with the SWIR region, visible and infrared (VNIR) spectral regions are less effected by atmosphere and, importantly, generally available for most sensors from different platforms in a high spatial resolution [84]. In our case, the wide ranges of spectral regions A and B were applicable from broad band satellite observations. In particular, regions A, B and C overlap with several VNIR bands of the Sentinel-2 sensor, which has high spatial resolution and short revisit time, indicating high potential for large scale monitoring of the effects of ambient ozone on soybean. Nevertheless, confirmation of the potential in satellite observations warrants a further, thorough investigation. 

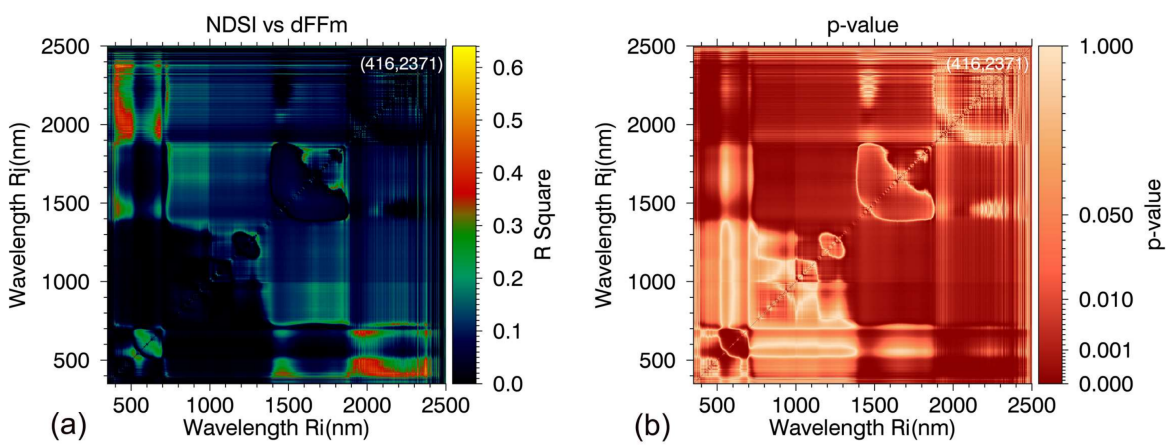

(c)

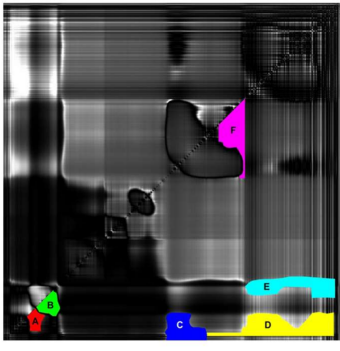

Figure 6. Coefficient of determination $\left(R^{2}\right)(\mathbf{a})$ and corresponding $p$-values $(\mathbf{b})$ between the fluorescence yield $\left(\triangle F / F m^{\prime}\right)$ and NDSI $\left(\mathrm{R}_{\mathrm{i}}, R_{\mathrm{j}}\right)$. (c) shows regions of interests that have large $R^{2}$ and high significance. The NDSI was calculated using complete spectrum reflectance combinations of two wavebands at $R_{i}$ and $\mathrm{R}_{\mathrm{j}}(n=30)$.

\subsection{Comparison with Existing Indices and Methods}

The location of a sample leaf on a plant may have some influence on observations, because leaf biochemical concentrations and light exposition showed decreasing trends, while leaf age and LAI increased in order of the upper, middle and lower canopy layers [43,85]. Our results show that for upper and middle leaf measurements, PRI, using $519 \mathrm{~nm}$ as the reference band wavelength, is the best for capturing plant physiological responses to ozone concentrations (Figure 7). Even though the observed relationship was not strong $\left(0.3<R^{2}<0.35\right)$, the selection of $519 \mathrm{~nm}$ aligns well with a previous study [35], which showed $512 \mathrm{~nm}$ as the best reference band to make PRI structurally robust. Overall, this finding is important as most optical remote sensing sensors actually measure the upper canopy.

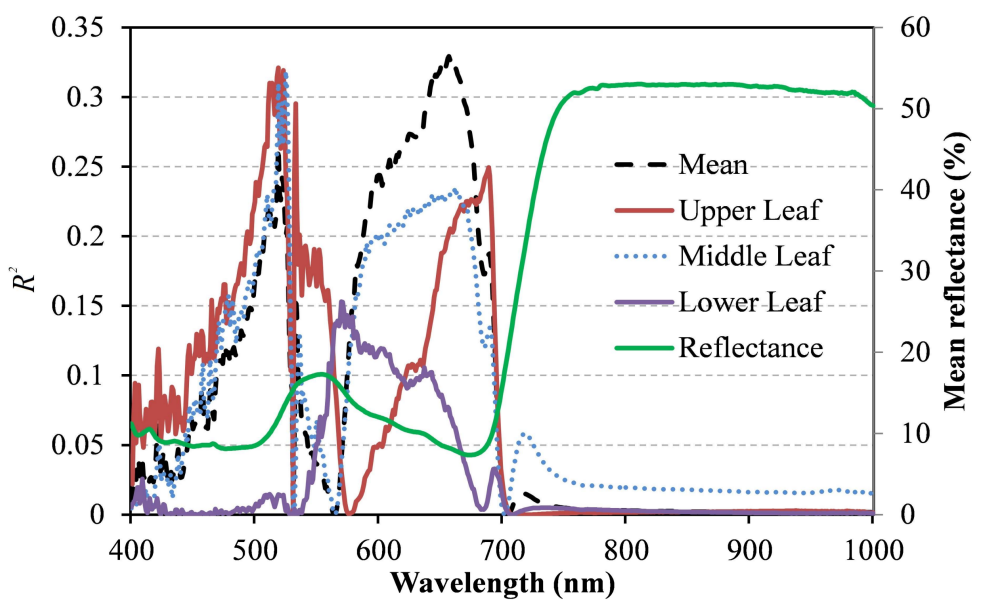

Figure 7. The relationship between fluorescence yield and PRI, calculated with varying reference bands in the range, 400-1000 nm. For all the leaf positions (upper, middle, lower and average leaf spectra), the relationship is strong when the reflectance of $519 \mathrm{~nm}$ wavelengths are used to formulate PRI. 
Based on the above relationship we formualted a new normalized difference spectral index and a photochemical reflectance index.

$$
\begin{gathered}
\text { NDSI }=(\text { R416 - R2371 }) /(R 416-\text { R2371 }) \\
\text { PRI519 }=(\text { R531 - 519) } /(\text { R531 + R519 })
\end{gathered}
$$

Figure 8 compares the correlation relationship between the spectral indices and physiological parameters, including fluorescence yield $\left(\Delta F / F m^{\prime}\right)$, electron transport rate $\left(E T R, \mu \mathrm{mol} \mathrm{m}^{-2} \mathrm{~s}^{-1}\right)$ and photochemical quenching (qP). Among the 27 indices, two indices developed in this study, i.e., $\mathrm{PRI}_{519}$ $\left[R_{531}, R_{519}\right]$ and NDSI [ $R_{419}, R_{2371}$, showed the strongest correlations compared to those from Table 2 . It is worth noting that ozone stress is best reflected by fluorescence yield, electron transport rate and photochemical quenching, while the strongest correlation with plant water stress was found with stomatal conductance [86].

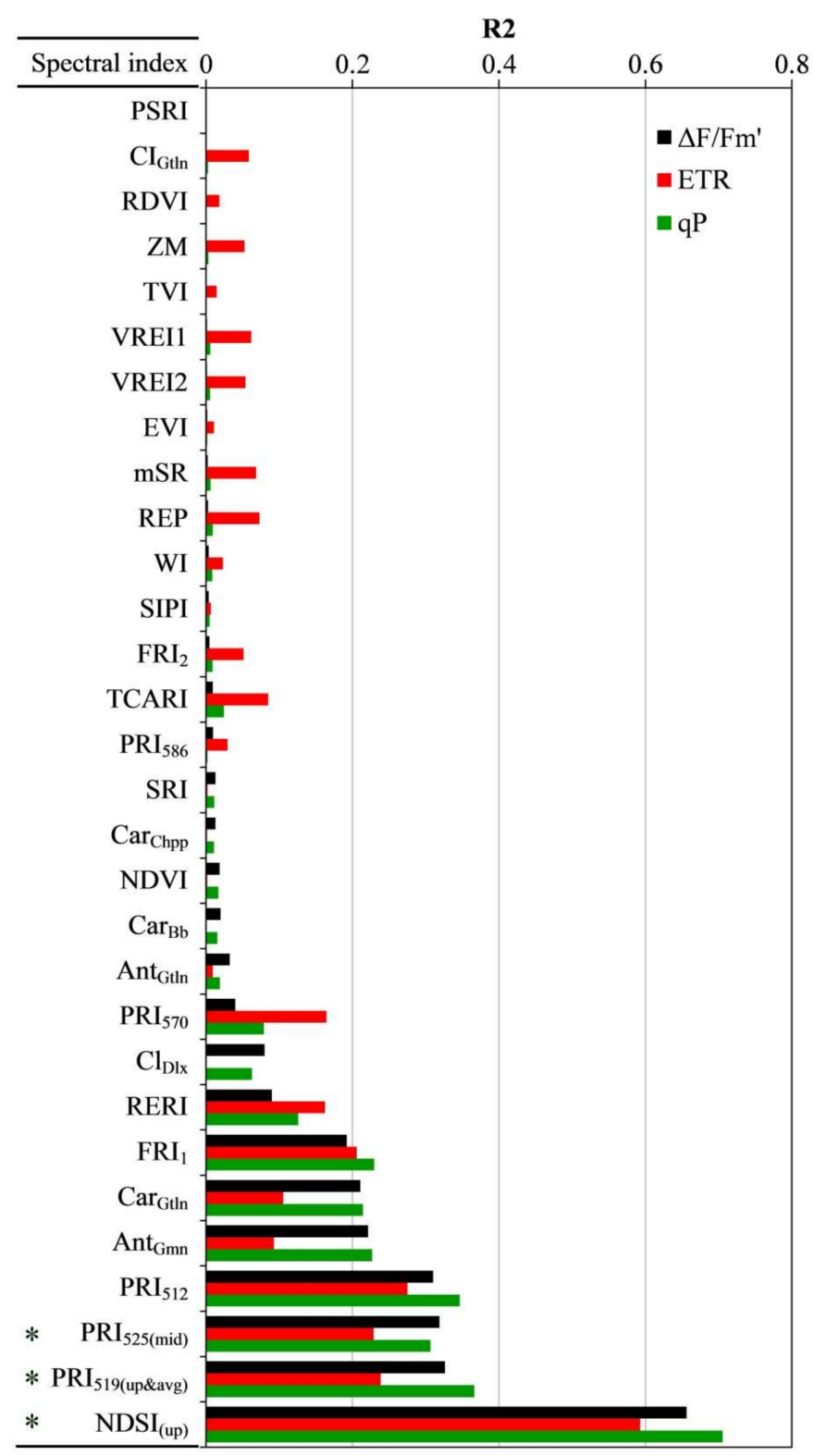

Figure 8. Comparison of correlations between the spectral indices and the physiological parameters. * denotes the indices proposed in this study. 


\subsection{Prediction of Mineral Nutrient Concentration}

The intent of PLSR modeling was to evaluate the feasibility of using leaf reflectance spectra as a nondestructive means to estimate leaf mineral nutrients and apply developed models to predict the nutrient concentration of soybean cultivars throughout the growing season. The best model was achieved between averaged spectral data with respect to both growth stages and genotypes. Datasets representing different growth stages and various cultivars allowed us to build general models increasing the chance of success in developing robust models for estimating nutrient concentration, thanks to the representativeness of larger dataset [87]. Table 3 presents the optimal models for mineral nutrient prediction. Coefficient of determination values $\left(R^{2}\right)$ during cross-validation ranged between 0.54 and 0.87 , indicating that $54-87 \%$ of variance in the mineral nutrients was explained by respective prediction models with RMSE\% ranging between 9.68-17.90\%. The models for macronutrients $\left(\mathrm{Ca}, \mathrm{K}\right.$ and $\mathrm{Mg}$ ) tended to have higher $R^{2}$ values $(>0.70)$ except for $\mathrm{Mn}$, compared to the $R^{2}(<0.70)$ of the prediction models for micronutrients ( $\mathrm{Cu}$ and $\mathrm{Fe}$ ). The better performance of the macronutrient models could be attributed to the higher concentration of nutrients, thus stronger spectral response [88]. The performances of micronutrient prediction models were comparable or superior to several existing studies. For example, [89] reported $R^{2}$ values of $0.65,0.73$, and 0.56 for $\mathrm{Ca}, \mathrm{K}$ and $\mathrm{Mg}$, respectively, using stepwise regression, averaged reflectance spectra of olive, heather, willow and mopane leaves. Similarly, [90] calibrated PLSR based macronutrient prediction models with continuum-removed reflectance spectra of Hyperion data over forested area had $R^{2}$ values for $\mathrm{Ca}, \mathrm{K}$ and $\mathrm{Mg}$ models of 0.08 , 0.31 and 0.86 , respectively.

Table 3. Results of the optimal model's performance in predicting mineral nutrients.

\begin{tabular}{ccccc}
\hline Mineral Nutrient & Number of LVs & $\boldsymbol{R}^{\mathbf{2}}$ & RMSE-CV (mg/kg) & RMSE\% \\
\hline $\mathrm{Ca}$ & 7 & 0.870 & 2023.450 & 9.68 \\
$\mathrm{Cu}$ & 6 & 0.671 & 2.096 & 15.60 \\
$\mathrm{Fe}$ & 5 & 0.542 & 19.846 & 9.95 \\
$\mathrm{~K}$ & 8 & 0.769 & 1187.543 & 10.68 \\
$\mathrm{Mg}$ & 6 & 0.704 & 348.820 & 13.37 \\
$\mathrm{Mn}$ & 6 & 0.720 & 21.781 & 17.90 \\
\hline
\end{tabular}

$\mathrm{LV}$, latent variable; $R^{2}$, coefficient of determination; RMSE-CV, root mean squared error of cross-validation; RMSE\%, relative RMSE-CV.

The regression coefficients of each wavelength in the prediction models are shown in Figure 9. The contributions of the visible and SWIR spectral regions were significant for predicting $\mathrm{Ca}, \mathrm{Cu}, \mathrm{Fe}$, $\mathrm{Mn}$ and $\mathrm{Mg}$, while near infrared spectral region was more important for $\mathrm{K}$ compared to the other spectral regions. In general, the visible spectral region appears to be highly significant for most of the nutrient prediction models, and this finding is well-aligned with previous studies [90,91]. In theory, there is no direct relationship between leaf reflectance spectra and mineral nutrient concentration, but reflectance spectra still can be used to predict nutrient concentration because of the spectrally active $\mathrm{C}-\mathrm{H}, \mathrm{N}-\mathrm{H}$, and $\mathrm{O}-\mathrm{H}$ bonds, which are highly dependent upon the chemical composition of the leaf tissue [92]. There exist inherent correlations between nutrients and leaf chemical components, such as organic matter, lignin, protein and pigments [93]. Ca does not have obvious spectral signature in near infrared spectral region, and $\mathrm{Mg}$ is an important constituent of the chlorophyll molecule. The significant contributions of visible and SWIR spectral regions in Ca and Mg prediction could be explained by the spectral responses of organic compounds and chlorophyll content [94]. Similarly, K is not spectrally active in the NIR spectral region, and the significant contribution of the NIR region could be attributed to the other chemical compounds that are sensitive to NIR [95]. The inferior performance of macronutrient prediction models for $\mathrm{Fe}, \mathrm{Cu}$ and $\mathrm{Mn}$ is mainly caused by low concentration levels $[96,97]$. However, [98] demonstrated the potential of the NIR and SWIR spectral regions in the detection of $\mathrm{Cu}$ deficiency in barley leaves at early stage and [97] showed the feasibility of predicting micronutrients ( $\mathrm{Fe}$ and $\mathrm{Mn}$ ) in orange leaves using visible spectral region. These results were further confirmed in the current study. 

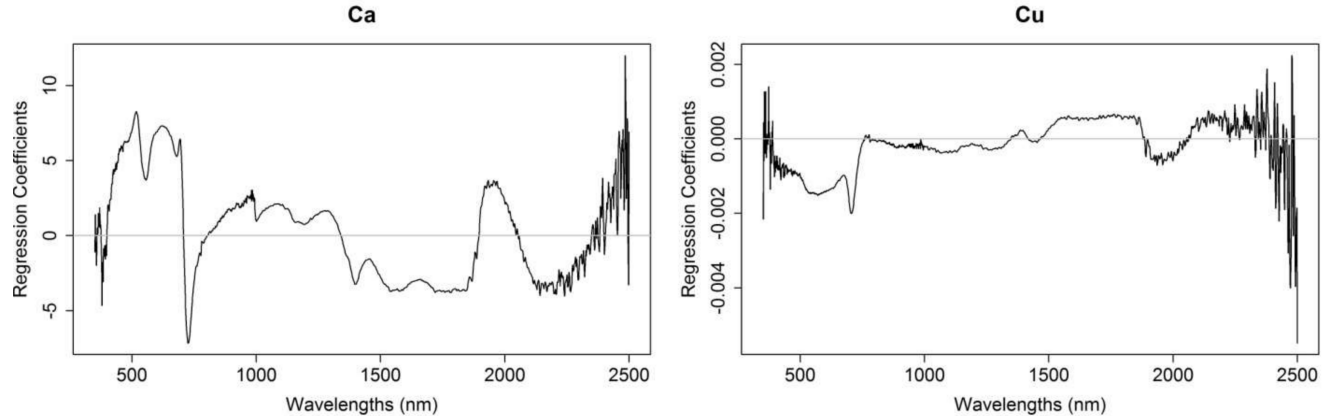

$\mathrm{Fe}$
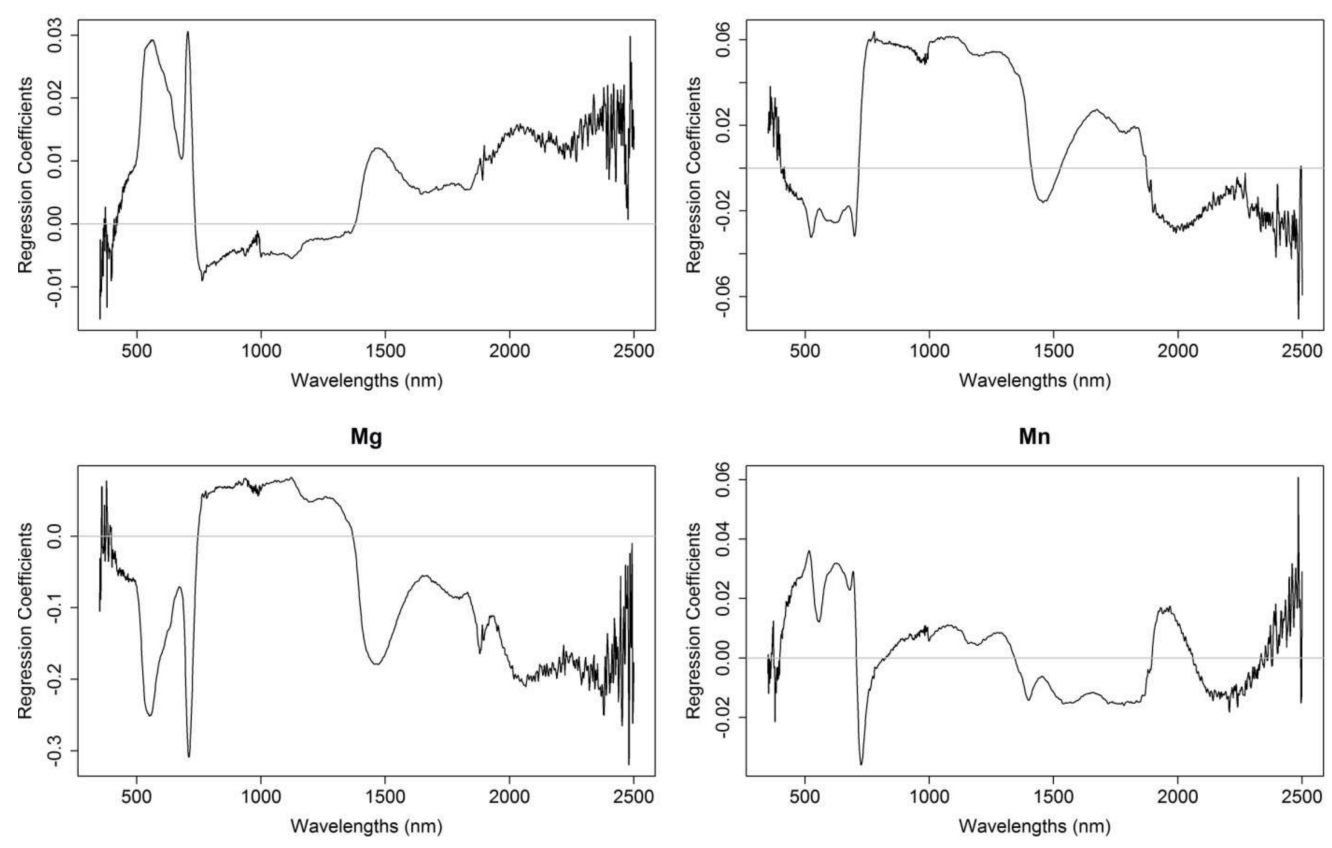

Figure 9. PSLR-coefficients for leaf nutrient concentration models.

\subsection{Temporal Variation in Mineral Nutrient Accumulation and Physiological Indices under Ambient Ozone Concentrations}

Elevated ambient ozone can negatively affect the soybean photosynthetic rate and thus, the nutrient concentration and yield. This negative effect differs between soybean genotypes [34]. Overall, the nutrient concentrations of soybean leaves were significantly affected by elevated ambient ozone, and nutrient concentrations showed clear separation among different soybean genotypes from 9 July 2014 (DOY 190) towards the end of growth, which was not the case for K (Figure 10). Ca, Mg and Mn concentrations decreased until 17 July 2014 (DOY 198); Ca and Mn steadily increased towards the end. The trend was similar for all soybean genotypes, while PI88788 had consistently low Ca, Mg and Mn concentrations starting from 2 July 2017 (DOY 183). Overall, a decrease in nutrient concentration is related to a dilution effect caused by a fast increase in biomass [99]. The decline in Ca and $\mathrm{Mg}$ at the beginning of the reproductive state could be attributed to the corresponding increase in $\mathrm{K}$, which intensifies the dilution effect and inhibits $\mathrm{Ca}$ and $\mathrm{Mg}$ uptake [100]. However, Ca and Mn reached their minimum values on 17 July 2014 (DOY 198) and continued to increase afterwards, regardless of the changes in K. Ca is considered to be a second messenger in plant metabolic regulation, and it increases in response to various biotic and abiotic stressors [101]. Furthermore, there is a strong positive correlation between Ca and Mn [102,103]; Hirschi et al. [104] reported that tobacco leaves with increased Mn became tolerant to it. Additionally, Jiménez et al. [105] found accumulated Mn towards the end of the reproductive cycle. The fluctuation in $\mathrm{Mg}$ could be explained by varying influences of pods and 
seeds that are known as sinks of soybean during reproductive stages. This unstable $\mathrm{Mg}$ concentration is consistent with the findings of [106]. However, PI88788 showed a dramatic decrease in $\mathrm{Mg}$ and reached the minimum value on 2 July 2014 (DOY 183), which was followed by a small increase but was still consistently lower than other genotypes. The low $\mathrm{Mg}$ concentration of PI88788 can be associated with decreased chlorophyll, as most Mg is found in chlorophyll molecules [107]. This result was also supported by the decreased chlorophyll index calculated from leaf spectra for the same growth stages [41]. Fe and $\mathrm{Cu}$ fluctuated around their mean values, possibly because they are immobile and not easy to move between different parts of plants [107]. Fe is necessary for biosynthesizing chlorophyll, and Fe deficiency is the main cause of chlorosis [108]. Fe showed a consistently higher concentration in PI88788, and this is almost the opposite of the Mg variation trend. The increased Fe could be attributed to the need for more chlorophyll to carry out normal photosynthetic activities. Here, it is worth mentioning that ambient ozone damage on sensitive cultivar became visible after 13 August 2014 (DOY 225). About half of all available $\mathrm{Cu}$ in plant tissue is located in the chloroplasts, where $\mathrm{Cu}$ plays an important role in electron transport reactions [109]. Thus, it is not surprising that the $\mathrm{Cu}$ concentration in PI88788 had a similar trend to $\mathrm{Mg}$ but was much smaller in range.
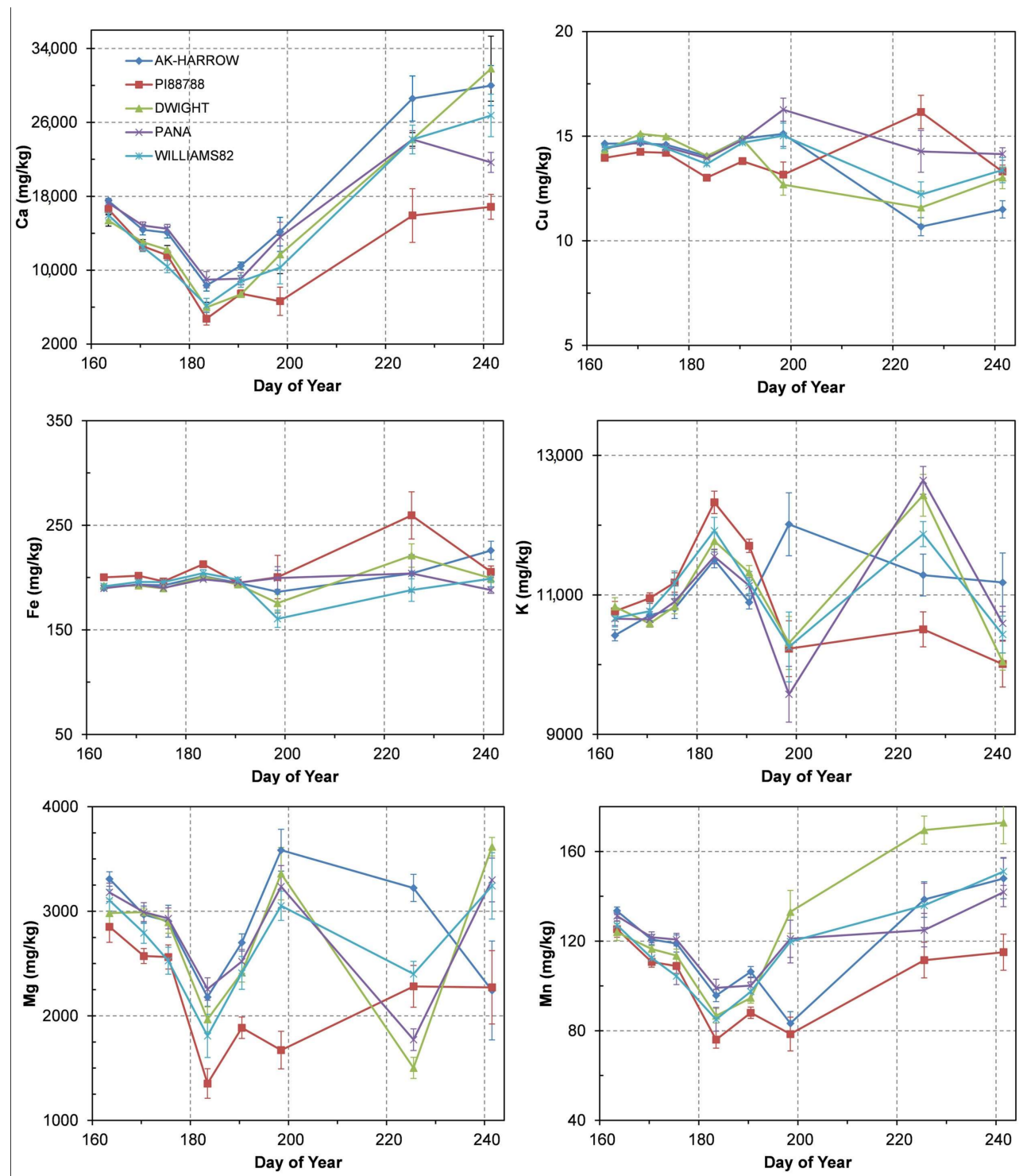

Figure 10. Changes in nutrient concentrations (mean and \pm standard error of the mean) by soybean genotypes over time. 
Temporal variation in daily 8 -h average ambient ozone concentrations (ppb), minimum $\left(T_{\min },{ }^{\circ} \mathrm{C}\right)$, maximum air temperature $\left(T_{\max },{ }^{\circ} \mathrm{C}\right), \mathrm{PRI}_{519}$ and NDSI values are shown in Figure 11. During the 2014 growing season, there were numerous days on which ozone concentrations exceeded $40 \mathrm{ppb}$ (AOT40), a threshold that can cause significant decline in crop yield by decreasing photosynthesis $[1,5]$. Ambient ozone concentration above the threshold was more prominent toward the end of the growing season, especially after 20 July 2014 . The PRI $I_{519}\left[R_{531}, R_{519}\right]$ and NDSI $\left[R_{419}, R_{2371}\right]$ of the five soybean genotypes showed great potential in terms of detecting responses of soybeans to ambient ozone. This was particularly true for NDSI [ $R_{419}, R_{2371}$, which is more sensitive for tracking plant physiological responses to changing ambient ozone concentrations compared to $\mathrm{PRI}_{519}\left[\mathrm{R}_{531}, \mathrm{R}_{519}\right]$.

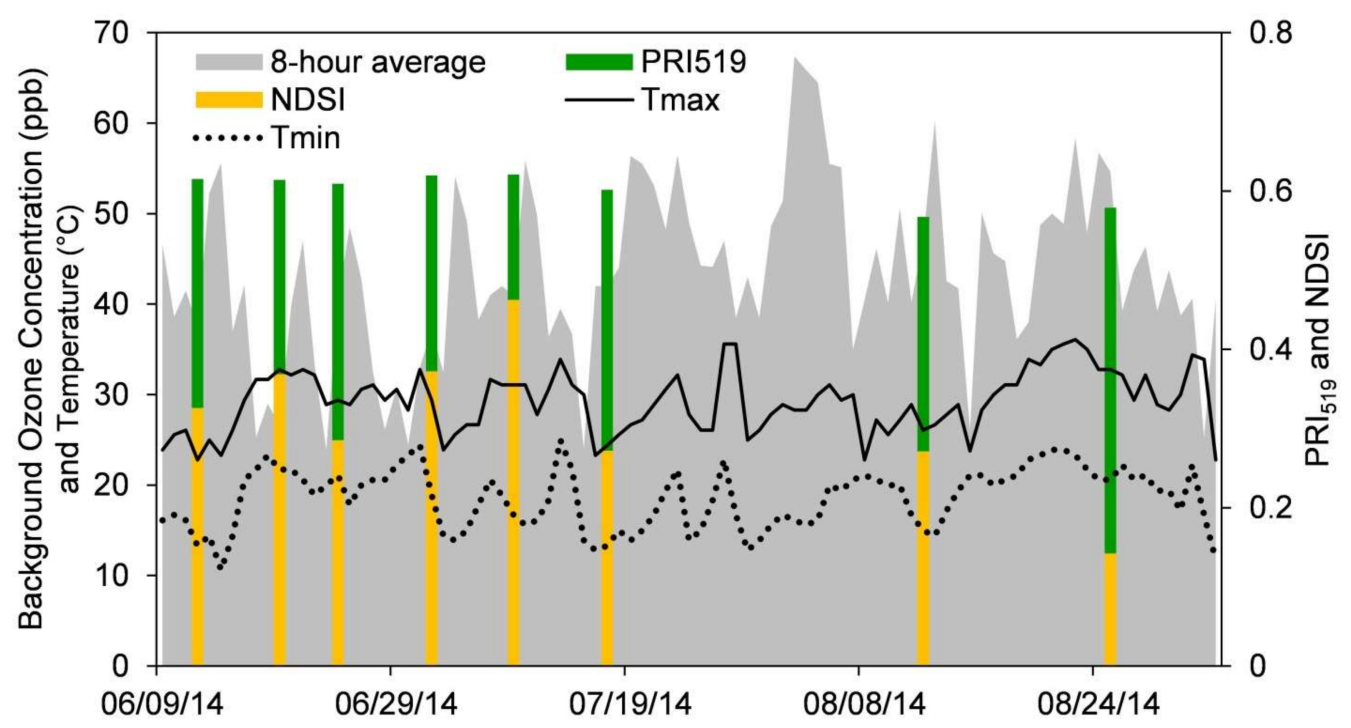

Figure 11. Temporal variation in daily 8 -h average ambient ozone concentrations (ppb); daily minimum $\left(T_{\text {min }},{ }^{\circ} \mathrm{C}\right)$ and maximum air temperature $\left(T_{\max },{ }^{\circ} \mathrm{C}\right) ; \mathrm{PRI}_{519}$ and NDSI.

Due to the activation of protective photosystem apparatus to prevent damage in high light conditions, the variations in the magnitude of fluorescence emission and photosynthesis were most significant in the afternoon when plants are exposed to high light conditions [110]. On 13 August 2014, we started fluorescence and photosynthesis measurements on AK-HARROW at 10 a.m. Each sampling took about 10-15 min, with six samples per genotype, and ended at 4 p.m. One may expect higher temperature, non-photochemical quenching and therefore, lower fluorescence for PANA and WILLIAMS82 as they were measured during the peak of high temperature stress. This may be one of the factors that complicated the inter-comparison of fluorescence between the cultivars. In fact, under low light unstressed conditions (no non-photochemical protection mechanisms activated) a negative correlation exists between fluorescence and photochemistry. Most studies have observed that in the presence of plant stress and high light conditions, fluorescence declines with photosynthesis (i.e., positive correlation) as a result of protective mechanisms (e.g., deactivation of the antenna, activation of the xanthophyll cycle and non-photochemical protection) which take place in the leaf to prevent damage caused by harmful radicals formed in such stress conditions [111].

\section{Conclusions}

This paper evaluated the responses of five soybean genotypes to ambient ozone in an open agricultural experiment using hyperspectral data and plant mineral nutrient concentrations. A suite of statistical, spectral, and modeling approaches, including NDSI and PLSR were utilized. The major conclusions include the following: 
(1) Chlorophyll fluorescence, photochemical quenching, electron transport, and harvest index varied significantly among the genotypes. The lowest photochemical quenching, fluorescence yield, harvest index, and terminal yield were found with the most ozone sensitive genotype PI88788, which was followed by AK-HARROW, the second most ozone sensitive genotype tested. The opposite was true for the most ozone tolerant genotypes: DWIGHT, PANA, and WILLIAMS82.

(2) Ambient ozone affects how plants regulate mineral nutrient uptake and tissue element composition. When plants were exposed to significant ozone damage, the foliar concentrations of $\mathrm{K}$ and $\mathrm{Mn}$ were lower and $\mathrm{Fe}$ and $\mathrm{Mg}$ concentrations were higher for ozone-sensitive genotypesAK-HARROW and PI88788 - than the rest of the genotypes.

(3) The analysis between the spectral data and leaf biophysical variables collected from the top, middle and bottom of a plant canopy demonstrated that the upper and middle leaf measurements are the best for capturing plant physiology in response to ozone concentrations. This finding is important as most optical remote sensing sensors measure upper canopy.

(4) Unlike water stress, which is strongly associated with changes in stomatal conductance, fluorescence yield was found to be the most correlated to ozone stress.

(5) Among the 27 indices found in the literature, the two indices developed in this study, i.e., $\mathrm{PRI}_{519}$ $\left[R_{531}, R_{519}\right]$ and NDSI [ $\left.R_{419}, R_{2371}\right]$, showed the strongest correlations with fluorescence yield, electron transport, and photochemical quenching, followed by $\mathrm{PRI}_{512}\left[\mathrm{R}_{531}, \mathrm{R}_{512}\right]$, Anthocyanin $\left(\right.$ Ant $\left._{\text {gmn }}\right)$, Carotenoid Index $\left(\mathrm{Car}_{\text {gtln }}\right)$, and Fluorescence Ratio Index1 $\left(\mathrm{FRI}_{1}=\mathrm{R} 690 / \mathrm{R} 600\right)$.

This contribution represents one of the very few studies involving the characterization of ambient ozone concentration on soybean crops in an open agricultural environment. Future research should focus on scaling up the results to satellite observations by conducting field-airborne-satellite simultaneous campaigns integrated with radiative transfer simulations. The SWIR wavelength $2371 \mathrm{~nm}$ was selected due to having the highest $\mathrm{R}$ square values among all bands. However, there are a number of high R-square hotspots in the VNIR region with R-square values very close to the highest R-square of the SWIR band. These VNIR regions, available from satellite sensors (Sentinel-2, Landsat, Worldview-2/3), provide wavelengths for satellite spectral indices.

Acknowledgments: We gratefully acknowledge substantial contributions to this work by Frank Dohleman, Josh Kinser from Monsanto; Elizabeth Ainsworth from the University of Illinois at Urbana-Champaign; Maitiniyazi Maimaitijiang, Guzhaliayi Sataer, and Joseph L. Wilkins from Saint Louis University. The paper was improved from the anonymous reviewers. This research was supported in part by NASA (NNH09ZDA001N, NNX13AB23A, NNX15AK03H), National Science Foundation (IIA-1355406 and IIA-1430427).

Author Contributions: Vasit Sagan and Jack Fishman conceived the idea, designed and supervised the experiment. Vasit Sagan wrote the bulk of the paper. Matthew Maimaitiyiming performed the experiment, analyzed the data and contributed to the writing of the paper.

Conflicts of Interest: The authors declare no conflict of interest. The funding sponsors had no role in the design of the study; in the collection, analyses, or interpretation of data; in the writing of the manuscript, or in the decision to publish the results.

\section{References}

1. Fishman, J.; Creilson, J.K.; Parker, P.A.; Ainsworth, E.A.; Vining, G.G.; Szarka, J.; Booker, F.L.; Xu, X.J. An investigation of widespread ozone damage to the soybean crop in the upper midwest determined from ground-based and satellite measurements. Atmos. Environ. 2010, 44, 2248-2256. [CrossRef]

2. Tai, A.P.K.; Martin, M.V.; Heald, C.L. Threat to future global food security from climate change and ozone air pollution. Nat. Clim. Chang. 2014, 4, 817-821. [CrossRef]

3. Alexandratos, N.; Bruinsma, J. World Agriculture towards 2030/2050: The 2012 Revision; Food and Agriculture Organization of the United Nations: Rome, Italy, 2012.

4. Betzelberger, A.M.; Gillespie, K.M.; Mcgrath, J.M.; Koester, R.P.; Nelson, R.L.; Ainsworth, E.A. Effects of chronic elevated ozone concentration on antioxidant capacity, photosynthesis and seed yield of 10 soybean cultivars. Plant Cell Environ. 2010, 33, 1569-1581. [CrossRef] [PubMed] 
5. Betzelberger, A.M.; Yendrek, C.R.; Sun, J.D.; Leisner, C.P.; Nelson, R.L.; Ort, D.R.; Ainsworth, E.A. Ozone exposure response for U.S. Soybean cultivars: Linear reductions in photosynthetic potential, biomass, and yield. Plant Physiol. 2012, 160, 1827-1839. [CrossRef] [PubMed]

6. MacDonald, J.M.; Korb, P.; Hoppe, R.A. Farm Size and the Organization of US Crop Farming; Createspace Independent Pub: North Charleston, SC, USA, 2013.

7. Avnery, S.; Mauzerall, D.L.; Liu, J.F.; Horowitz, L.W. Global crop yield reductions due to surface ozone exposure: 1. Year 2000 crop production losses and economic damage. Atmos. Environ. 2011, 45, 2284-2296. [CrossRef]

8. Avnery, S.; Mauzerall, D.L.; Liu, J.F.; Horowitz, L.W. Global crop yield reductions due to surface ozone exposure: 2. Year 2030 potential crop production losses and economic damage under two scenarios of $\mathrm{O}_{3}$ pollution. Atmos. Environ. 2011, 45, 2297-2309. [CrossRef]

9. Gitelson, A.; Merzlyak, M.N. Quantitative estimation of chlorophyll-a using reflectance spectraExperiments with autumn chestnut and maple leaves. J. Photochem. Photobiol. B 1994, 22, 247-252. [CrossRef]

10. Gitelson, A.A.; Vina, A.; Arkebauer, T.J.; Rundquist, D.C.; Keydan, G.; Leavitt, B. Remote estimation of leaf area index and green leaf biomass in maize canopies. Geophys. Res. Lett. 2003, 30. [CrossRef]

11. Penuelas, J.; Filella, I.; Gamon, J.A. Assessment of photosynthetic radiation-use efficiency with spectral reflectance. New Phytol. 1995, 131, 291-296. [CrossRef]

12. Zarco-Tejada, P.J.; Pushnik, J.C.; Dobrowski, S.; Ustin, S.L. Steady-state chlorophyll a fluorescence detection from canopy derivative reflectance and double-peak red-edge effects. Remote Sens. Environ. 2003, 84, $283-294$. [CrossRef]

13. Ceccato, P.; Flasse, S.; Gregoire, J.M. Designing a spectral index to estimate vegetation water content from remote sensing data-Part 2. Validation and applications. Remote Sens. Environ. 2002, 82, 198-207. [CrossRef]

14. Ghulam, A.; Li, Z.L.; Qin, Q.M.; Tong, Q.X.; Wang, J.H.; Kasimu, A.; Zhu, L. A method for canopy water content estimation for highly vegetated surfaces-shortwave infrared perpendicular water stress index. Sci. China Ser. D 2007, 50, 1359-1368. [CrossRef]

15. Ghulam, A.; Li, Z.L.; Qin, Q.M.; Yimit, H.; Wang, J.H. Estimating crop water stress with ETM plus NIR and swir data. Agric. For. Meteorol. 2008, 148, 1679-1695. [CrossRef]

16. Fumagalli, I.; Gimeno, B.S.; Velissariou, D.; De Temmerman, L.; Mills, G. Evidence of ozone-induced adverse effects on crops in the mediterranean region. Atmos. Environ. 2001, 35, 2583-2587. [CrossRef]

17. Mills, G.; Hayes, F.; Simpson, D.; Emberson, L.; Norris, D.; Harmens, H.; Buker, P. Evidence of widespread effects of ozone on crops and (semi-)natural vegetation in Europe (1990-2006) in relation to AOT40-and flux-based risk maps. Glob. Chang. Biol. 2011, 17, 592-613. [CrossRef]

18. Jackson, R.D.; Idso, S.B.; Reginato, R.J.; Pinter, P.J., Jr. Canopy temperature as a crop water stress indicator. Water Resour. Res. 1981, 17, 1133-1138. [CrossRef]

19. Moran, M.S.; Clarke, T.R.; Inoue, Y.; Vidal, A. Estimating crop water-deficit using the relation between surface-air temperature and spectral vegetation index. Remote Sens. Environ. 1994, 49, 246-263. [CrossRef]

20. Zarco-Tejada, P.J.; Gonzalez-Dugo, V.; Berni, J.A.J. Fluorescence, temperature and narrow-band indices acquired from a UAV platform for water stress detection using a micro-hyperspectral imager and a thermal camera. Remote Sens. Environ. 2012, 117, 322-337. [CrossRef]

21. Sepulcre-Canto, G.; Zarco-Tejada, P.J.; Sobrino, J.A.; Berni, J.A.J.; Jimenez-Munoz, J.C.; Gastellu-Etchegorry, J.P. Discriminating irrigated and rainfed olive orchards with thermal ASTER imagery and DART 3D simulation. Agric. For. Meteorol. 2009, 149, 962-975. [CrossRef]

22. Panigada, C.; Rossini, M.; Meroni, M.; Cilia, C.; Busettoa, L.; Amaducci, S.; Boschetti, M.; Cogliati, S.; Picchi, V.; Pinto, F.; et al. Fluorescence, PRI and canopy temperature for water stress detection in cereal crops. Int. J. Appl. Earth Obs. Geoinf. 2014, 30, 167-178. [CrossRef]

23. Dobrowski, S.Z.; Pushnik, J.C.; Zarco-Tejada, P.J.; Ustin, S.L. Simple reflectance indices track heat and water stress-induced changes in steady-state chlorophyll fluorescence at the canopy scale. Remote Sens. Environ. 2005, 97, 403-414. [CrossRef]

24. Joiner, J.; Yoshida, Y.; Vasilkov, A.P.; Yoshida, Y.; Corp, L.A.; Middleton, E.M. First observations of global and seasonal terrestrial chlorophyll fluorescence from space. Biogeosciences 2011, 8, 637-651. [CrossRef]

25. Gamon, J.A.; Serrano, L.; Surfus, J.S. The photochemical reflectance index: An optical indicator of photosynthetic radiation use efficiency across species, functional types, and nutrient levels. Oecologia 1997, 112, 492-501. [CrossRef] [PubMed] 
26. Carter, G.A.; Miller, R.L. Early detection of plant stress by digital imaging within narrow stress-sensitive wavebands. Remote Sens. Environ. 1994, 50, 295-302. [CrossRef]

27. Carter, G.A.; Cibula, W.G.; Miller, R.L. Narrow-band reflectance imagery compared with thermal imagery for early detection of plant stress. J. Plant Physiol. 1996, 148, 515-522. [CrossRef]

28. Carter, G.A. Responses of leaf spectral reflectance to plant stress. Am. J. Bot. 1993, 80, 239-243. [CrossRef]

29. Carter, G.A. Reflectance wavebands and indices for remote estimation of photosynthesis and stomatal conductance in pine canopies. Remote Sens. Environ. 1998, 63, 61-72. [CrossRef]

30. Eitel, J.U.H.; Vierling, L.A.; Litvak, M.E.; Long, D.S.; Schulthess, U.; Ager, A.A.; Krofcheck, D.J.; Stoscheck, L. Broadband, red-edge information from satellites improves early stress detection in a New Mexico conifer woodland. Remote Sens. Environ. 2011, 115, 3640-3646. [CrossRef]

31. Maxwell, K.; Johnson, G.N. Chlorophyll fluorescence-A practical guide. J. Exp. Bot. 2000, 51, $659-668$. [CrossRef] [PubMed]

32. Campbell, P.K.E.; Middleton, E.M.; McMurtrey, J.E.; Corp, L.A.; Chappelle, E.W. Assessment of vegetation stress using reflectance or fluorescence measurements. J. Environ. Qual. 2007, 36, 832-845. [CrossRef] [PubMed]

33. Gray, S.B.; Dermody, O.; DeLucia, E.H. Spectral reflectance from a soybean canopy exposed to elevated $\mathrm{CO}_{2}$ and $\mathrm{O}_{3}$. J. Exp. Bot. 2010, 61, 4413-4422. [CrossRef] [PubMed]

34. Ainsworth, E.A.; Serbin, S.P.; Skoneczka, J.A.; Townsend, P.A. Using leaf optical properties to detect ozone effects on foliar biochemistry. Photosynth. Res. 2014, 119, 65-76. [CrossRef] [PubMed]

35. Hernandez-Clemente, R.; Navarro-Cerrillo, R.M.; Suarez, L.; Morales, F.; Zarco-Tejada, P.J. Assessing structural effects on PRI for stress detection in conifer forests. Remote Sens. Environ. 2011, 115, 2360-2375. [CrossRef]

36. Tuncturk, M.; Tuncturk, R.; Yasar, F. Changes in micronutrients, dry weight and plant growth of soybean (Glycine max L. Merrill) cultivars under salt stress. Afr. J. Biotechnol. 2008, 7, 1650-1654.

37. Hede, A.N.H.; Kashiwaya, K.; Koike, K.; Sakurai, S. A new vegetation index for detecting vegetation anomalies due to mineral deposits with application to a tropical forest area. Remote Sens. Environ. 2015, 171, 83-97. [CrossRef]

38. Knight, H. Calcium signaling during abiotic stress in plants. Int. Rev. Cytol. 2000, 195, 269-324. [PubMed]

39. Kreuzwieser, J.; Gessler, A. Global climate change and tree nutrition: Influence of water availability. Tree Physiol. 2010, 30, 1221-1234. [CrossRef] [PubMed]

40. Utrillas, M.J.; Alegre, L.; Simon, E. Seasonal-changes in production and nutrient content of Cynodon-dactylon (L.) pers subjected to water deficits. Plant Soil 1995, 175, 153-157. [CrossRef]

41. Ghulam, A.; Fishman, J.; Maimaitiyiming, M.; Wilkins, J.L.; Maimaitijiang, M.; Welsh, J.; Bira, B.; Grzovic, M. Characterizing crop responses to background ozone in open-air agricultural field by using reflectance spectroscopy. IEEE Geosci. Remote Sens. Lett. 2015, 12, 1307-1311. [CrossRef]

42. Krupa, S.; McGrath, M.T.; Andersen, C.P.; Booker, F.L.; Burkey, K.O.; Chappelka, A.H.; Chevone, B.I.; Pell, E.J.; Zilinskas, B.A. Ambient ozone and plant health. Plant Dis. 2001, 85, 4-12. [CrossRef]

43. Gara, T.W.; Darvishzadeh, R.; Skidmore, A.K.; Wang, T. Impact of vertical canopy position on leaf spectral properties and traits across multiple species. Remote Sens. 2018, 10, 346. [CrossRef]

44. Li, H.; Zhao, C.; Huang, W.; Yang, G. Non-uniform vertical nitrogen distribution within plant canopy and its estimation by remote sensing: A review. Field Crop Res. 2013, 142, 75-84. [CrossRef]

45. Genty, B.; Briantais, J.M.; Baker, N.R. The relationship between the quantum yield of photosynthetic electron transport and quenching of chlorophyll fluorescence. Biochim. Biophys. Acta 1989, 990, 87-92. [CrossRef]

46. Munger, P.; Bleiholder, H.; Hack, H.; Hess, M.; Stauss, R.; Boom, T.; Weber, E. Phenological growth stages of the soybean plant (Glycine max L. Merr.): Codification and description according to the bbch scale. J. Agron. Crop Sci. 1997, 179, 209-217. [CrossRef]

47. Veley, K.M.; Berry, J.C.; Fentress, S.J.; Schachtman, D.P.; Baxter, I.; Bart, R. High-throughput profiling and analysis of plant responses over time to abiotic stress. Plant Direct 2017, 1. [CrossRef]

48. Clarkson, D.T.; Hanson, J.B. The mineral nutrition of higher plants. Annu. Rev. Plant Physiol. 1980, 31, 239-298. [CrossRef]

49. Donald, C.M.; Hamblin, J. The biological yield and harvest index of cereals as agronomic and plant breeding criteria. In Advances in Agronomy; Brady, N.C., Ed.; Academic Press: Cambridge, MA, USA, 1976; Volume 28, pp. 361-405. 
50. Fishman, J.; Belina, K.M.; Encarnaciòn, C.H. The St. Louis ozone garden: Visualizing the impact of a changing atmosphere. Bull. Am. Meteorol. Soc. 2014, 95, 1171-1176. [CrossRef]

51. Gamon, J.; Surfus, J. Assessing leaf pigment content and activity with a reflectometer. New Phytol. 1999, 143, 105-117. [CrossRef]

52. Gitelson, A.A.; Merzlyak, M.N.; Chivkunova, O.B. Optical properties and nondestructive estimation of anthocyanin content in plant leaves. Photochem. Photobiol. 2001, 74, 38-45. [CrossRef]

53. Gitelson, A.A.; Zur, Y.; Chivkunova, O.B.; Merzlyak, M.N. Assessing carotenoid content in plant leaves with reflectance spectroscopy. Photochem. Photobiol. 2002, 75, 272-281. [CrossRef]

54. Chappelle, E.W.; Kim, M.S.; McMurtrey, J.E. Ratio analysis of reflectance spectra (RARS): An algorithm for the remote estimation of the concentrations of chlorophyll $a$, chlorophyll $b$, and carotenoids in soybean leaves. Remote Sens. Environ. 1992, 39, 239-247. [CrossRef]

55. Blackburn, G.A. Quantifying chlorophylls and caroteniods at leaf and canopy scales: An evaluation of some hyperspectral approaches. Remote Sens. Environ. 1998, 66, 273-285. [CrossRef]

56. Delalieux, S.; Zarco-Tejada, P.J.; Tits, L.; Jimenez Bello, M.A.; Intrigliolo, D.S.; Somers, B. Unmixing-based fusion of hyperspatial and hyperspectral airborne imagery for early detection of vegetation stress. IEEE J. Sel. Top. Appl. Earth Obs. Remote Sens. 2014, 7, 2571-2582. [CrossRef]

57. Gitelson, A.; Merzlyak, M.N. Spectral reflectance changes associated with autumn senescence of Aesculus hippocastanum L. And Acer platanoides L. Leaves. Spectral features and relation to chlorophyll estimation. J. Plant Physiol. 1994, 143, 286-292. [CrossRef]

58. Huete, A.; Didan, K.; Miura, T.; Rodriguez, E.P.; Gao, X.; Ferreira, L.G. Overview of the radiometric and biophysical performance of the MODIS vegetation indices. Remote Sens. Environ. 2002, 83, 195-213. [CrossRef]

59. Sims, D.A.; Gamon, J.A. Relationships between leaf pigment content and spectral reflectance across a wide range of species, leaf structures and developmental stages. Remote Sens. Environ. 2002, 81, 337-354. [CrossRef]

60. Rouse, J.W.; Haas, R.H.; Schell, J.A.; Deering, D.W. Monitoring Vegetation Systems in the Great Plains with ERTS; NASA: College Station, TX, USA, 1974; pp. 309-317.

61. Gamon, J.A.; Peñuelas, J.; Field, C.B. A narrow-waveband spectral index that tracks diurnal changes in photosynthetic efficiency. Remote Sens. Environ. 1992, 41, 35-44. [CrossRef]

62. Merzlyak, M.N.; Gitelson, A.A.; Chivkunova, O.B.; Rakitin, V.Y.U. Non-destructive optical detection of pigment changes during leaf senescence and fruit ripening. Physiol. Plant. 1999, 106, 135-141. [CrossRef]

63. Zarco-Tejada, P.J.; Miller, J.R.; Noland, T.L.; Mohammed, G.H.; Sampson, P.H. Scaling-up and model inversion methods with narrowband optical indices for chlorophyll content estimation in closed forest canopies with hyperspectral data. IEEE Trans. Geosci. Remote Sens. 2001, 39, 1491-1507. [CrossRef]

64. Guyot, G.; Baret, F. Utilisation de la haute resolution spectrale pour suivre l'etat des couverts vegetaux. Spectr. Signat. Objects Remote Sens. 1988, 287.

65. Roujean, J.-L.; Breon, F.-M. Estimating par absorbed by vegetation from bidirectional reflectance measurements. Remote Sens. Environ. 1995, 51, 375-384. [CrossRef]

66. Jordan, C.F. Derivation of leaf-area index from quality of light on the forest floor. Ecology 1969, 50, 663-666. [CrossRef]

67. Penuelas, J.; Baret, F.; Filella, I. Semi-empirical indices to assess carotenoids/chlorophyll a ratio from leaf spectral reflectance. Photosynthetica 1995, 31, 221-230.

68. Haboudane, D.; Miller, J.R.; Tremblay, N.; Zarco-Tejada, P.J.; Dextraze, L. Integrated narrow-band vegetation indices for prediction of crop chlorophyll content for application to precision agriculture. Remote Sens. Environ. 2002, 81, 416-426. [CrossRef]

69. Broge, N.H.; Leblanc, E. Comparing prediction power and stability of broadband and hyperspectral vegetation indices for estimation of green leaf area index and canopy chlorophyll density. Remote Sens. Environ. 2001, 76, 156-172. [CrossRef]

70. Vogelmann, J.E.; Rock, B.N.; Moss, D.M. Red edge spectral measurements from sugar maple leaves. Int. J. Remote Sens. 1993, 14, 1563-1575. [CrossRef]

71. PeÑUelas, J.; Filella, I.; Biel, C.; Serrano, L.; SavÉ, R. The reflectance at the $950-970 \mathrm{~nm}$ region as an indicator of plant water status. Int. J. Remote Sens. 1993, 14, 1887-1905. [CrossRef] 
72. R Development Core Team. R: A Language and Environment for Statistical Computing [internet]; R Foundation for Statistical Computing: Vienna, Austria, 2011.

73. Unkovich, M.; Baldock, J.; Forbes, M. Chapter 5-Variability in harvest index of grain crops and potential significance for carbon accounting: Examples from Australian agriculture. Adv. Agron. 2010, 105, 173-219.

74. Bayuelo-Jimenez, J.S.; Debouck, D.G.; Lynch, J.P. Growth, gas exchange, water relations, and ion composition of Phaseolus species grown under saline conditions. Field Crops Res. 2003, 80, 207-222. [CrossRef]

75. Koyro, H.W. Effect of high NaCl-salinity on plant growth, leaf morphology, and ion composition in leaf tissues of Beta vulgaris ssp. maritima. J. Appl. Bot.-Angew. Bot. 2000, 74, 67-73.

76. Wang, M.; Zheng, Q.S.; Shen, Q.R.; Guo, S.W. The critical role of potassium in plant stress response. Int. J. Mol. Sci. 2013, 14, 7370-7390. [CrossRef] [PubMed]

77. Marschner, H.; Marschner, P. Marschner's Mineral Nutrition of Higher Plants, 3rd ed.; Elsevier/Academic Press: London, UK; Waltham, MA, USA, 2012; p. 651.

78. Ramoliya, P.J.; Patel, H.M.; Pandey, A.N. Effect of salinisation of soil on growth and macro- and micro-nutrient accumulation in seedlings of Acacia catechu (Mimosaceae). Ann. Appl. Biol. 2004, 144, 321-332. [CrossRef]

79. Tuncturk, M.; Tuncturk, R.; Yildirim, B.; Ciftci, V. Changes of micronutrients, dry weight and plant development in canola (Brassica Napus L.) cultivars under salt stress. Afr. J. Biotechnol. 2011, 10, 3726-3730.

80. Venkatesalu, V.; Kumar, R.R.; Chellappan, K.P. Growth and mineral distribution of Sesuvium-portulacastrum L., a salt-marsh halophyte, under sodium-chloride stress. Commun. Soil Sci. Plant Anal. 1994, 25, 2797-2805. [CrossRef]

81. McCree, K.J. The action spectrum, absorptance and quantum yield of photosynthesis in crop plants. Agric. Meteorol. 1971, 9, 191-216. [CrossRef]

82. Strasser, R.; Schwarz, R.; Eggenberg, P. Fluorescence routine tests to describe the behaviour of a plant in its environment. In Applications of Chlorophyll Fluorescene in Photosynthesis Research, Stress Physiology, Hydrobiology and Remote Sensing; Springer: Berlin, Germany, 1988; pp. 181-187.

83. Gitelson, A.A.; Kaufman, Y.J.; Merzlyak, M.N. Use of a green channel in remote sensing of global vegetation from EOS-MODIS. Remote Sens. Environ. 1996, 58, 289-298. [CrossRef]

84. Zarco-Tejada, P.J.; González-Dugo, V.; Williams, L.E.; Suárez, L.; Berni, J.A.J.; Goldhamer, D.; Fereres, E. A pri-based water stress index combining structural and chlorophyll effects: Assessment using diurnal narrow-band airborne imagery and the CWSI thermal index. Remote Sens. Environ. 2013, 138, 38-50. [CrossRef]

85. Shiraiwa, T.; Sinclair, T.R. Distribution of nitrogen among leaves in soybean canopies. Crop Sci. 1993, 33, 804-808. [CrossRef]

86. Maimaitiyiming, M.; Ghulam, A.; Bozzolo, A.; Wilkins, J.L.; Kwasniewski, M.T. Early detection of plant physiological responses to different levels of water stress using reflectance spectroscopy. Remote Sens. 2017, 9, 745. [CrossRef]

87. Vigneau, N.; Ecarnot, M.; Rabatel, G.; Roumet, P. Potential of field hyperspectral imaging as a non destructive method to assess leaf nitrogen content in Wheat. Field Crop Res. 2011, 122, 25-31. [CrossRef]

88. Van Maarschalkerweerd, M.; Husted, S. Recent developments in fast spectroscopy for plant mineral analysis. Front. Plant Sci. 2015, 6, 169. [CrossRef] [PubMed]

89. Ferwerda, J.G.; Skidmore, A.K. Can nutrient status of four woody plant species be predicted using field spectrometry? ISPRS J. Photogramm. Remote Sens. 2007, 62, 406-414. [CrossRef]

90. Gökkaya, K.; Thomas, V.; Noland, T.L.; McCaughey, H.; Morrison, I.; Treitz, P. Prediction of macronutrients at the canopy level using spaceborne imaging spectroscopy and lidar data in a mixedwood boreal forest. Remote Sens. 2015, 7, 9045-9069. [CrossRef]

91. Mutanga, O.; Skidmore, A.K.; Prins, H. Predicting in situ pasture quality in the Kruger National Park, South Africa, using continuum-removed absorption features. Remote Sens. Environ. 2004, 89, 393-408. [CrossRef]

92. Elvidge, C.D. Visible and near infrared reflectance characteristics of dry plant materials. Remote Sens. 1990, 11, 1775-1795. [CrossRef]

93. Cozzolino, D.; Moron, A. Exploring the use of near infrared reflectance spectroscopy (NIRS) to predict trace minerals in legumes. Anim. Feed Sci. Technol. 2004, 111, 161-173. [CrossRef]

94. Ruano-Ramos, A.; García-Ciudad, A.; García-Criado, B. Near infrared spectroscopy prediction of mineral content in botanical fractions from semi-arid grasslands. Anim. Feed Sci. Technol. 1999, 77, 331-343. [CrossRef] 
95. Ward, A.; Nielsen, A.L.; Møller, H. Rapid assessment of mineral concentration in meadow grasses by near infrared reflectance spectroscopy. Sensors 2011, 11, 4830-4839. [CrossRef] [PubMed]

96. Embleton, T.W.; Jones, W.W.; Labanauskas, C.K.; Reuther, W. Leaf analysis as a diagnostic tool and guide to fertilization. Citrus Ind. 1973, 3, 183-210.

97. Menesatti, P.; Antonucci, F.; Pallottino, F.; Roccuzzo, G.; Allegra, M.; Stagno, F.; Intrigliolo, F. Estimation of plant nutritional status by Vis-NIR spectrophotometric analysis on orange leaves [Citrus sinensis (L.) osbeck cv tarocco]. Biosyst. Eng. 2010, 105, 448-454. [CrossRef]

98. Van Maarschalkerweerd, M.; Bro, R.; Egebo, M.; Husted, S. Diagnosing latent copper deficiency in intact barley leaves (Hordeum vulgare, L.) using near infrared spectroscopy. J. Agric. Food Chem. 2013, 61, 10901-10910. [CrossRef] [PubMed]

99. Hill, J.; Robson, A.; Loneragan, J. The effect of copper supply on the senescence and the retranslocation of nutrients of the oldest leaf of wheat. Ann. Bot. 1979, 44, 279-287. [CrossRef]

100. Schimansky, C. The influence of certain experimental parameters on the flux characteristics of $\mathrm{Mg}-28$ in the case of barley seedlings in hydroculture experiments. Landwirtsch. Forsch. 1981, 34, 154-163.

101. Lecourieux, D.; Ranjeva, R.; Pugin, A. Calcium in plant defence-signalling pathways. New Phytol. 2006, 171, 249-269. [CrossRef] [PubMed]

102. Chen, Z.; Watanabe, T.; Shinano, T.; Ezawa, T.; Wasaki, J.; Kimura, K.; Osaki, M.; Zhu, Y.G. Element interconnections in lotus japonicus: A systematic study of the effects of element additions on different natural variants. Soil Sci. Plant Nutr. 2009, 55, 91-101. [CrossRef]

103. Wu, Z.; Liang, F.; Hong, B.; Young, J.C.; Sussman, M.R.; Harper, J.F.; Sze, H. An endoplasmic reticulum-bound $\mathrm{Ca}^{2+} / \mathrm{Mn}^{2+}$ pump, ECA1, supports plant growth and confers tolerance to $\mathrm{Mn}^{2+}$ stress. Plant Physiol. 2002, 130, 128-137. [CrossRef] [PubMed]

104. Hirschi, K.D.; Korenkov, V.D.; Wilganowski, N.L.; Wagner, G.J. Expression of arabidopsis CAX2 in tobacco. Altered metal accumulation and increased manganese tolerance. Plant Physiol. 2000, 124, 125-134. [CrossRef] [PubMed]

105. Jiménez, M.P.; Effrón, D.; de la Horra, A.M.; Defrieri, R. Foliar potassium, calcium, magnesium, zinc, and manganese content in soybean cultivars at different stages of development. J. Plant Nutr. 1996, 19, 807-816. [CrossRef]

106. Drossopoulos, J.B.; Bouranis, D.L.; Bairaktari, B.D. Patterns of mineral nutrient fluctuations in soybean leaves in relation to their position. J. Plant Nutr. 1994, 17, 1017-1035. [CrossRef]

107. Taiz, L.; Zeiger, E. Plant Physiology, 5th ed.; Sinauer Associates: Sunderland, MA, USA, 2010.

108. Marsh, H., Jr.; Evans, H.; Matrone, G. Investigations of the role of iron in chlorophyll metabolism. II. Effect of iron deficiency on chlorophyll synthesis. Plant Physiol. 1963, 38, 638-642. [CrossRef] [PubMed]

109. Hänsch, R.; Mendel, R.R. Physiological functions of mineral micronutrients ( $\mathrm{Cu}, \mathrm{Zn}, \mathrm{Mn}, \mathrm{Fe}, \mathrm{Ni}, \mathrm{Mo}, \mathrm{B}, \mathrm{Cl})$. Curr. Opin. Plant Biol. 2009, 12, 259-266. [CrossRef] [PubMed]

110. Van der Tol, C.; Verhoef, W.; Rosema, A. A model for chlorophyll fluorescence and photosynthesis at leaf scale. Agric For. Meteorol. 2009, 149, 96-105. [CrossRef]

111. Meroni, M.; Rossini, M.; Guanter, L.; Alonso, L.; Rascher, U.; Colombo, R.; Moreno, J. Remote sensing of solar-induced chlorophyll fluorescence: Review of methods and applications. Remote Sens. Environ. 2009, 113, 2037-2051. [CrossRef]

(C) 2018 by the authors. Licensee MDPI, Basel, Switzerland. This article is an open access article distributed under the terms and conditions of the Creative Commons Attribution (CC BY) license (http://creativecommons.org/licenses/by/4.0/). 